\title{
The Generation of Monoclonal Antibodies that Bind Preferentially to Adrenal Chromaffin Cells and the Cells of Embryonic Sympathetic Ganglia
}

\author{
Josette F. Carnahan a and Paul H. Patterson \\ Biology Division, California Institute of Technology, Pasadena, California 91125
}

\begin{abstract}
Adrenal chromaffin cells, sympathetic neurons, and small intensely fluorescent (SIF) cells are each derived from the neural crest, produce catecholamines, and share certain morphological features. These cell types are also partially interconvertible in cell culture (Doupe et al., 1985a,b; Anderson and Axel, 1986). Thus, these cells are said to be members of the sympathoadrenal (SA) lineage and could share a common progenitor. To investigate the origins of this lineage further, we used the cyclophosphamide immunosuppression method (Matthew and Patterson, 1983) to generate five monoclonal antibodies (SA1-5) that bind strongly to chromaffin cells, with little or no labeling of sympathetic neurons or SIF cells in frozen sections from adult rats. Competition experiments indicate that these antibodies bind to at least three distinct epitopes in tissue sections. The SA antibodies also label most of the cells of embryonic sympathetic ganglia and adrenal primordia. Labeling of sympathetic ganglia appears as the cells initially coalesce and express high levels of tyrosine hydroxylase (TH). Not all $\mathrm{TH}^{+}$ cells in the embryo are SA 1-5', however; carotid body SIF cells, nodose ganglion $\mathrm{TH}^{+}$cells, and the transiently $\mathrm{TH}^{+}$cells in the dorsal root ganglia do not display detectable SA1-5 labeling. Thus, the expression of these markers for the SA1-5 lineage is selective. SA antigen expression is hormonally controlled; removal of glucocorticoid and addition of NGF to cultured adrenal chromatfin cells result in the loss of SA 1-5 labeling. These results suggest that the presumed precursors for sympathetic neurons and SIF cells initially express chromaffin cell markers.
\end{abstract}

It is generally thought that development involves both a progressive restriction in the range of possible fates, as well as a gradual expression of molecules specific for particular differentiation pathways or lineages. There are, however, very few cases in the vertebrate nervous system in which a lineage has been studied in sufficient detail so that successive stages of differentiation and commitment can be delineated. A significant

\footnotetext{
Received Jan. 25, 1991; revised May 1, 1991; accepted June 11, 1991.

This work was supported by the NINDS (Javits Neuroscience Investigator Award) and a McKnight Foundation Neuroscience Research Project Award to P.H.P. We thank David Anderson for constructive comments on the experiments and on the manuscript, Doreen McDowell for help with tissue culture materials, and To Ha Thai and Susan Ou for help with monoclonal antibody preparation.

Correspondence should be addressed to Paul H. Patterson, Division of Biology, 216-76, California Institute of Technology, Pasadena, CA 91125.

" Present address: Amgen, Inc., Amgen Center, Thousand Oaks, CA 913201789.

Copyright $(\mathcal{C} 1991$ Society for Neuroscience $0270-6474 / 91 / 113493-14 \$ 05.00 / 0$
}

technical limitation in this effort is the lack of markers specific for the various stages of development within a particular lineage. Without such markers, cells making key phenotypic decisions cannot be identified. It has been especially difficult to find molecular labels for committed progenitor cells. Monoclonal antibodies can be used as highly specific markers, and the hybridoma method can be manipulated so as to enhance the likelihood of obtaining antibodies against rare antigens of interest (Matthew and Patterson, 1983; Barald and Wessels, 1984; Agius and Richman, 1986; Barclay and Smith, 1986; Golumbeski and Dimond, 1986; Hockfield, 1987; Mahana et al., 1987; Matthew and Sandrock, 1987; Norton and Benjamini, 1987; Huse et al., 1989; Chaudhary et al., 1990). We have used the cyclophosphamide immunosuppression method (Matthew and Patterson, 1983; Matthew and Sandrock, 1987; Ou et al., 1991) to produce a number of antibodies that shed new light on the early stages of the sympathoadrenal (SA) lineage.

The cells of the SA lineage are derived from the neural crest, and they include the neurons and small intensely fluorescent (SIF) cells of sympathetic ganglia, and the chromaffin cells of the adrenal medulla and the extraadrenal chromaffin bodies (Le Douarin, 1982). While these cells all produce catecholamines that are secreted in response to electrical stimulation, they can be distinguished by morphological criteria, including the size of the cell body, the presence or absence of neuronal processes, the size of transmitter-storing vesicles, and the intensity of their catecholaminc histofluorescencc (cf. Doupc ct al., 1985a,b). Molecular differences include the level of tyrosine hydroxylase (TH) and the presence of neuron-specific markers such as SCG10 and neurofilament (NF) (Anderson and Axel, 1986). The epinephrine synthesizing enzyme, phenylethanolamine $N$-methyl transferase (PNMT), can also be used as a marker for chromaffin cells, but not all chromaffin cells express the enzyme (Bohn et al., 1981; Coupland and Tomlinson, 1989).

While each of the three major cell types in this lineage expresses a stable differentiated phenotype in the adult organism, the cells can be interconverted. Studies of single cells in culture have demonstrated that chromaffin cells from neonatal or adult rat adrenal glands can be made to extend processes and transform into normal sympathetic neurons (Unsicker et al., 1978, 1985; Doupe et al., 1985a; Unsicker and Lietzke, 1987; Seidl and Unsicker, 1989). Similarly, individual SIF cells can be converted into chromaffin cells or neurons (Doupe et al., 1985b). SIF and chromaffin cell survival and differentiation are promoted by glucocorticoid (Eränkö et al., 1972; Soinila and Eränkö, 1984; Doupe et al., 1985a,b), while neuronal differentiation is enhanced by NGF (Unsicker et al., 1978; Doupe et al., 1985a) 
and basic fibroblast growth factor (bFGF) (Claude et al., 1988; Stemple et al., 1988). Similar interconversions may occur in vivo following manipulation of these factors; glucocorticoid injections in neonatal rats increase the number of SIF cells in sympathetic ganglia (Eränkö and Eränkö, 1972; Päivärinta and Eränkö, 1982; Päivärinta et al., 1984), NGF injections result in the replacement of adrenal chromaffin cells by sympathetic neurons (Aloe and Levi-Montalcini, 1979), and injcctions of antiNGF antibodies diminish neuronal number while enhancing the number of SIF cells (J. F. Carnahan and P. H. Patterson, unpublished observations).

These in vitro and in vivo observations suggest that the various SA cell types are derived from a common progenitor, rather than each following an independent line of differentiation from the neural crest (Landis and Patterson, 1981; Anderson, 1989; Unsicker et al., 1989). In fact, bipotential cells that can give rise to chromaffin cells or neurons in culture have been derived from neonatal rat sympathetic ganglia (Jacobowitz and Greene, 1974; Doupe et al., 1985b) and embryonic adrenal medullae (Anderson and Axel, 1986; Seidl and Unsicker, 1989). In addition, cell lines were produced from embryonic adrenal medulla that respond to bFGF by the expression of neuronal markers, and this differentiation can be delayed by growth in glucocorticoid (Birren and Anderson, 1990). In an effort to identify SA progenitor cells in situ and to develop tools for isolating them from embryonic ganglia, we sought to produce monoclonal antibodies that selectively bind to the progenitors. Our approach was based on observations that suggested that the putative progenitor cells share properties in common with chromaffin and SIF cells. For example, the cells of the early embryonic ganglia express high levels of TH and catecholamine histofluorescence as do chromaffin and SIF cells (Eränkö and Eränkö, 1977; Mascorro and Yates, 1980; Taxi et al., 1983; Soinila, 1984; Soinila and Eränkö, 1984), and the latter cells can give rise to neurons in culture, as discussed above. Therefore, certain antibodies that bind to antigens expressed in chromaffin cells but not in sympathetic neurons might also bind embryonic SA progenitor cells. We injected mice with adult rat sympathetic ganglia and suppressed the response with cyclophosphamide, and then injected the mice with neonatal rat adrenal medullac. In this way, the mice were tolerized to antigens shared between neurons and chromaffin cells. We describe the properties of five monoclonal antibodies (SA1-5) that bind adult rat chromaffin cells but not sympathetic neurons.

Some of this work has appeared previously in preliminary form (Carnahan and Patterson, 1988).

\section{Materials and Methods}

\section{Production of monoclonal antibodies}

Antigen preparation. Adrenal medullae of neonatal (1-3 d) SpragueDawley rats (Simonsen Laboratories, Gilroy, CA) were rapidly separated from the adrenal cortex by dissection on ice, in L-15-air medium (Hawrot and Patterson, 1979). Both cortex and medullae were saved. Adult rat superior cervical ganglia (SCG) were dissected, and cleaned in L-15-air medium on ice. If not processed immediately, the tissues were frozen at $-20^{\circ} \mathrm{C}$. Tissues were homogenized using a clean glass homogenizer in phosphate-buffered saline (PBS) (M. A. Bioproducts, Walkersville, MD) containing $5 \mathrm{~mm}$ phenylmethylsulfonyl fluoride (PMSF; Sigma, St. Louis, MO) and $25 \mathrm{~mm}$ ethylenediaminetetraacetic acid (EDTA; Sigma), pH 7.4, on ice. Homogenates were centrifuged in an Airfuge at 30 psi for $30 \mathrm{~min}$. Pellets were resuspended, sonicated lightly on ice, and assayed for protein using the Bradford assay (BioRad, Richmond, CA; bulletin 1069), using bovine serum albumin (BSA) as the standard.

Hybridoma production. RBF/m (Taggart and Samloff, 1983) and Balb/c mice were injected with antigens according to the schedule described below. The myeloma cells used for the fusions were HL-1 (Taggart and Samloff, 1983) for both RBF and Balb/c mice. Antigen injections contained about $100 \mu \mathrm{g}$ of membrane protein prepared in $500 \mu 1$ of PBS containing $25 \mathrm{~mm}$ EDTA and $3 \mathrm{~mm}$ PMSF as protease inhibitors. Complete Freund's adjuvant (CFA) was obtained from GIBCO Laboratories (Detroit, MI). Injection schedule:

Day 1: SCG and adrenal cortical membranes, in PBS (i.p.), plus cyclophosphamide (120 mg/kg; Cytoxan, Mead Johnson).

Day 2: cyclophosphamide only (i.p.), same dose.

Day 3: cyclophosphamide only (i.p.), same dose.

Day 22: adrenal medulla membranes, in CFA (i.p.).

Day 40: adrenal medulla membranes, in PBS, intravenously in tail.

Day 43: fusion, using $5.2 \times 10^{7}$ HLI-653 myeloma cells and $10^{8}$ splenocytes according to the method of Köhler and Milstein (1975). Cells were plated at a density of $2 \times 10^{6} / \mathrm{ml}$, with $150 \mu \mathrm{l} /$ well (i.e., $3 \times$ $10^{5}$ cells/well).

\section{Secretion assay}

Antibody secretion was assayed by applying $1 \mu \mathrm{l}$ of each hybridoma supernatant to a nitrocellulose membrane (Schleicher \& Schuell Inc., Keene, NH) (Hawkes et al., 1982). After drying at room temperature (RT) for $1 \mathrm{hr}$, membranes were blocked by incubation in PBS containing $10 \%$ normal goat serum (NGS) for $1 \mathrm{hr}$ with gentle shaking and then incubated for $1 \mathrm{hr}$ at RT with goat anti-mouse IgG conjugated to peroxidase (Chemicon International Inc.), diluted 1:100 in PBS containing $2 \%$ NGS. Membranes were washed three times with PBS plus $2 \%$ NGS, 5 min each, and three times with PBS. The peroxidase reaction was revealed by incubating the membranes in a solution of 5 vol of PBS plus $1 \mathrm{vol}$ of $3 \mathrm{mg} / \mathrm{ml} \mathrm{4-chloronaphtol} \mathrm{(Merck)} \mathrm{in} \mathrm{methanol} \mathrm{and} \mathrm{acti-}$ vated with $0.01 \% \mathrm{H}_{2} \mathrm{O}_{2}$.

\section{Immunohistochemistry}

Freshly dissected tissues were rapidly frozen in O.C.T. Tissue Tek (Milles) on dry ice. Sections (7-10 $\mu \mathrm{m})$ were cut on a cryostat (Hacker Instruments Inc.), collected on multispot microscopic slides (C. A. Hendley, Essex, England), and air dried. Sections were either used immediately or stored at $-30^{\circ} \mathrm{C}$ for $2-3$ weeks. Embryonic tissue, however, was never kept frozen for longer than a few days, even after fixation. If the specimen had been fixed, the slides were gelatin coated to increase their adhesivity.

Immunostaining of fresh-frozen sections involved a first step of blocking nonspecific binding of the primary antibody for $30 \mathrm{~min}$ at RT with PBS containing $10 \%$ NGS. Sections were then incubated for $1 \mathrm{hr}$ at RT, or overnight at $4^{\circ} \mathrm{C}$, with monoclonal antibody or a rabbit antiserum. Sections were washed by three incubations of $5 \mathrm{~min}$ each of PBS plus $2 \%$ NGS and then blocked again using PBS plus 10\% NGS, 30-60 min at RT. Secondary antibody (high-fluorescein-conjugated, goat anti-mouse IgG; Antibodies, Inc.) or biotinylated horse anti-mouse IgG (Vector Laboratories) was incubated on the sections with an equal volume of rat serum (to decrease nonspecific binding) for $30 \mathrm{~min}$, on ice. Before use, secondary antibodies were diluted (usually 1:100 in PBS plus 2\% NGS) and centrifuged in an Eppendorf centrifuge for 5-10 min.

For double staining, a high-fluorescein anti-mouse antibody was used to detect monoclonal antibodies, and a biotinylated goat anti-rabbit antibody (Vector Laboratories) was used to detect rabbit polyclonal antibodies; these were incubated on sections simultaneously for $1 \mathrm{hr}$ at RT. After washing as described above, sections were rinsed three additional times with PBS to remove all serum (known to contain biotin). Staining was concluded by incubating sections for 15-30 min at RT with streptavidin-Texas red (Amersham), diluted 1:100 in PBS. Double staining with two monoclonal antibodies (HNK-1, an IgM, and SA1, an IgG1) was used prior to the availability of biotinylated SA2. Isotypespecific secondary antibodies [rhodamine-conjugated goat anti-mouse IgM (TAGO) and fluorescein isothiocyanate (FITC) goat anti-mouse IgG (Southern Biotech, Inc., Atlanta)] were used to distinguish the monoclonal antibodies. Sections were briefly rinsed and mounted using glycerol containing a $10 \%$ solution of PBS, $\mathrm{pH} 8.0$, and $10 \mathrm{mg} / \mathrm{ml}$ phenylenediamine (Johnson and de Nogueira Araujo, 1981) to reduce fading of fluorescence. Sections were examined on an inverted Zeiss microscope with epiillumination fluorescence using an FITC filter set (excitation 450-490 nM, emission 515-565 nM), a Texas red filter set (excitation $530-585 \mathrm{nM}$, emission $615 \mathrm{nM}$ ), or a rhodamine filter set (excitation 510-560 nM, emission $590 \mathrm{~nm}$ ). 
Table 1. Monoclonal antibodies resulting from two fusions

\begin{tabular}{|c|c|c|c|c|c|c|}
\hline \multirow[b]{2}{*}{ Mouse strain } & \multicolumn{2}{|c|}{$\begin{array}{l}\text { Antibody } \\
\text { secretion }\end{array}$} & \multicolumn{4}{|c|}{ Histochemical staining } \\
\hline & $\%$ & Total & $\mathrm{AM}+\mathrm{SCG}$ & Neither & AM only & SCG only \\
\hline $\mathrm{RBF} / \mathrm{m}$ & 80 & 275 & 40 & 39 & 14.5 & 5.5 \\
\hline Balb/c & 19 & 10 & 40 & 30 & 30 & 0 \\
\hline
\end{tabular}

Two independent fusions, using RBF/m and Balb/c mice, were carried out as described in Materials and Methods. Hybridoma supernatants were initially assayed for the presence of antibody using a dot blot method. The first two data columns denote the percentage of hybridoma-containing wells that contained antibodies (\%) and the corresponding absolute number of secreting hybridomas.(Total). Antibodies were screened for their binding to unfixed, frozen sections of adult and neonatal SCG and neonatal adrenal medullae (AM). The histochemical results are expressed as percentages of the total number of antibodies screened for that fusion.

Staining for TH, PNMT, and NF involved fixing animals; adult rats were anesthetized with ether and perfused through the heart using a 23 gauge needle with PBS, followed by $4 \%$ paraformaldehyde in 0.1 м PBS, pH 7.4. For embryonic tissue, the animal was divided into three or four segments and fixed in 4\% paraformaldehyde in PBS for several hours at $4^{\circ} \mathrm{C}$. The pieces were then immersed in $20 \%$ sucrose in PBS until they sank to the bottom of the container, whereupon they were frozen and sectioned. The rabbit anti-TH antiserum (Eugene International, Inc.) was diluted 1:100. Neurofilament staining was visualized using a $1: 100$ diluted rabbit antiserum to melanocyte stimulating hormone (antiMSH; Immunonuclear Corp.), which was shown to detect the $140 \mathrm{kDa}$ NF subunit (Dräger et al., 1983). Anti-PNMT rabbit antiserum was a gift from Dr. M. Bohn (National Science Foundation). Anti-PNMT staining involved incubation in $10 \mathrm{~mm}$ PBS, pH 7.6, containing $0.5 \mathrm{~mm}$ $\mathrm{NaCl}$; blocking steps were in this buffer, containing $10 \%$ horse serum, $3 \%$ NGS, and $0.3 \%$ Nonidet P-40.

Fixation of cultured cells involved rinsing the dishes with PBS and exposure to $4 \%$ paraformaldehyde for $10 \mathrm{~min}$, on ice. Fresh fixative solution at $\mathrm{pH} 7.4$ was used, and $0.1 \%$ Tween 20 was routinely included to permeabilize the cells. The staining protocol was as for tissue sections.

\section{Biotinylation of antibodies}

Ascites fluids were generated according to Galfre and Milstein (1981), and antibodies were partially purified by ammonium sulfate precipitation. After resuspension and dialysis against PBS, $\mathrm{pH} 8.0$, containing $30 \mathrm{~mm} \mathrm{NaCl}$, antibodies were further purified on a DE-52 column (Whatman) (Hudson and Hay, 1980) and concentrated using a Centricon 30 device (Amicon). Prior to biotinylation, antibodies were dialyzed

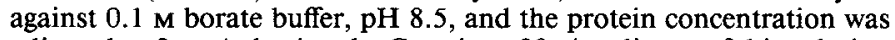
adjusted to $2 \mathrm{mg} / \mathrm{ml}$ using the Centricon 30 . An aliquot of this solution $(100 \mu \mathrm{g} ; 50 \mu \mathrm{l})$ was added to $20 \mu \mathrm{l}$ of biotinamidocaproate $N$-hydroxysuccimide ester ( $30 \mu \mathrm{M}$ in dimethyl sulfoxide; Sigma) and incubated for $1 \mathrm{hr}$ at RT. To stop the reaction, $5 \mu \mathrm{l}$ of $2 \mathrm{M}$ glycine was added for 5 $\min$. The antibody solution was diluted with PBS and centrifuged three times in a Centricon 30 to remove unbound biotin. Labeled antibodies were frozen in aliquots until use. Histological staining of fresh-frozen sections of neonatal adrenal glands revealed that the SA2 antibody maintained its original titer of binding to sections after biotinylation.

\section{Competition experiment}

The staining of biotinylated antibody SA2 was assessed after coincubation with each unlabeled sympathoadrenal (SA) antibody on sections of unfixed, neonatal rat adrenal medulla. The concentration of labeled SA2 was chosen so that a clear diminution of staining was observed when it was diluted twofold with PBS. The concentration of each unlabeled antibody was $>10$-fold higher than that required for optimal staining using indirect immunofluorescence. Incubation with unlabeled SA2 abolished the staining by labeled SA2.

\section{Primary culture of chromaffin cells}

Cell preparation. Neonatal rat adrenal medullae were dissected free of cortex in L-15-air. Chromaffin cells were dissociated using a modification of the method of Unsicker et al. (1978). After a brief wash in calcium/magnesium-free Hanks' balanced salt solution (HBSS; GIB$\mathrm{CO}$ ), medullae were incubated at $37^{\circ} \mathrm{C}$ for $40 \mathrm{~min}$ in $1 \mathrm{mg} / \mathrm{ml}$ collagenase (Worthington Biochemical Corp., Freehold, NJ) and $5 \mathrm{mg} / \mathrm{ml}$ dispase
(Sigma) in the same HBSS. The resulting cell suspension was centrifuged at $100 \times g$ twice, resuspended in growth medium, and plated at 5001000 cells per well.

Culture dishes and substrata. The $5 \mathrm{~mm}$ wells were made by attaching Aclar (Allied Chemical Corp., Morristown, NJ) coverslips to Petri dishes with paraffin according to Hawrot and Patterson (1979). The dishes were sterilized by UV irradiation and coated with $50 \mu$ l of a Matrigel solution (Collaborative Research) as described by Stemple et al. (1988). Alternatively, wells were coated with rat tail collagen (Hawrot and Patterson, 1979). Similar results were obtained with both surfaces, but neurite outgrowth was faster on the Matrigel-coated coverslips.

Culture media. Cells were plated in L-15-air and grown in L-15-CO growth medium as described by Doupe et al. (1985a). The growth medium was supplemented with $5 \%$ rat serum. Other additives included $1 \mu \mathrm{M}$ dexamethasone phosphate (Merck, Sharp \& Dohme) and $1 \mu \mathrm{g} / \mathrm{ml}$ 7S NGF (Mains and Patterson, 1973).

\section{Results}

Generation of cell-specific antibodies by immunosuppression Two independent fusions were carried out, using $\mathrm{RBF} / \mathrm{m}$ mice for one and $\mathrm{Balb} / \mathrm{c}$ mice for the other. The $\mathrm{RBF} / \mathrm{m}$ strain is used to enhance the frequency of antibody-secreting hybridomas (Taggart and Samloff, 1983). Our results with dot blots confirmed the increased efficiency of RBF/m-derived hybridomas ( $80 \%$ of the wells contained secreting antibodies, for a total of 275 antibody-secreting hybridomas; Table 1) as compared to the commonly used Balb/c strain (19\% and 10; Table 1). Although this particular Balb/c fusion yielded an unusually low number of hybridomas and percentage of secretors, $\mathrm{RBF} / \mathrm{m}$ mice routinely yield higher numbers in our hands.

All antibody ${ }^{+}$supernatants were screened for binding to unfixed, frozen sections of adult and neonatal rat SCG and neonatal rat adrenal medullae, using standard immunohistochemical methods. The distribution of binding in these tissues was quite similar in both fusions (Table 1). The results demonstrate the effectiveness of the cyclophosphamide method, in that many more antibodies bound to the nonsuppressed antigen (adrenal medulla, 43) than to the suppressed antigen (sympathetic ganglion, 18). Many other fusions, using the same procedures but without suppression, have demonstrated that there is no difficulty in generating antibodies against SCG membranes (J. Imrich and $\mathrm{P}$. H. Patterson, unpublished observations).

\section{SA1-5 binding to chromaffin cells versus sympathetic neurons}

Seven clones were selected from the $\mathrm{RBF} / \mathrm{m}$ fusion for further analysis. Five of these (SA 1-5) displayed bright staining of cells in the adult adrenal medulla and little or no staining of adult sympathetic ganglia. The other two adrenal medulla-selective antibodies appeared to bind extracellular material; no further experiments were carried out with these antibodies. The differ- 


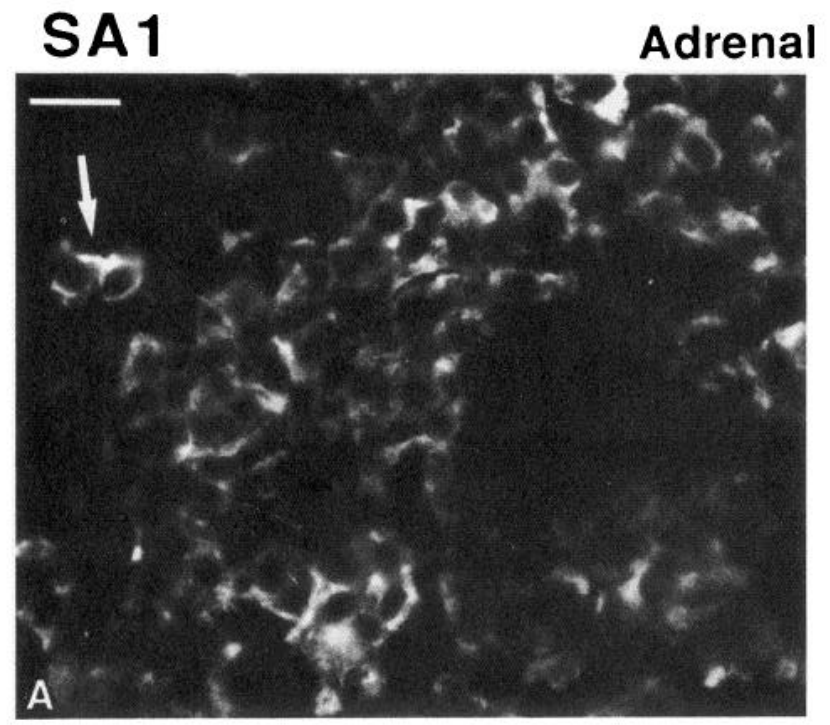

\section{Medulla}

PNMT
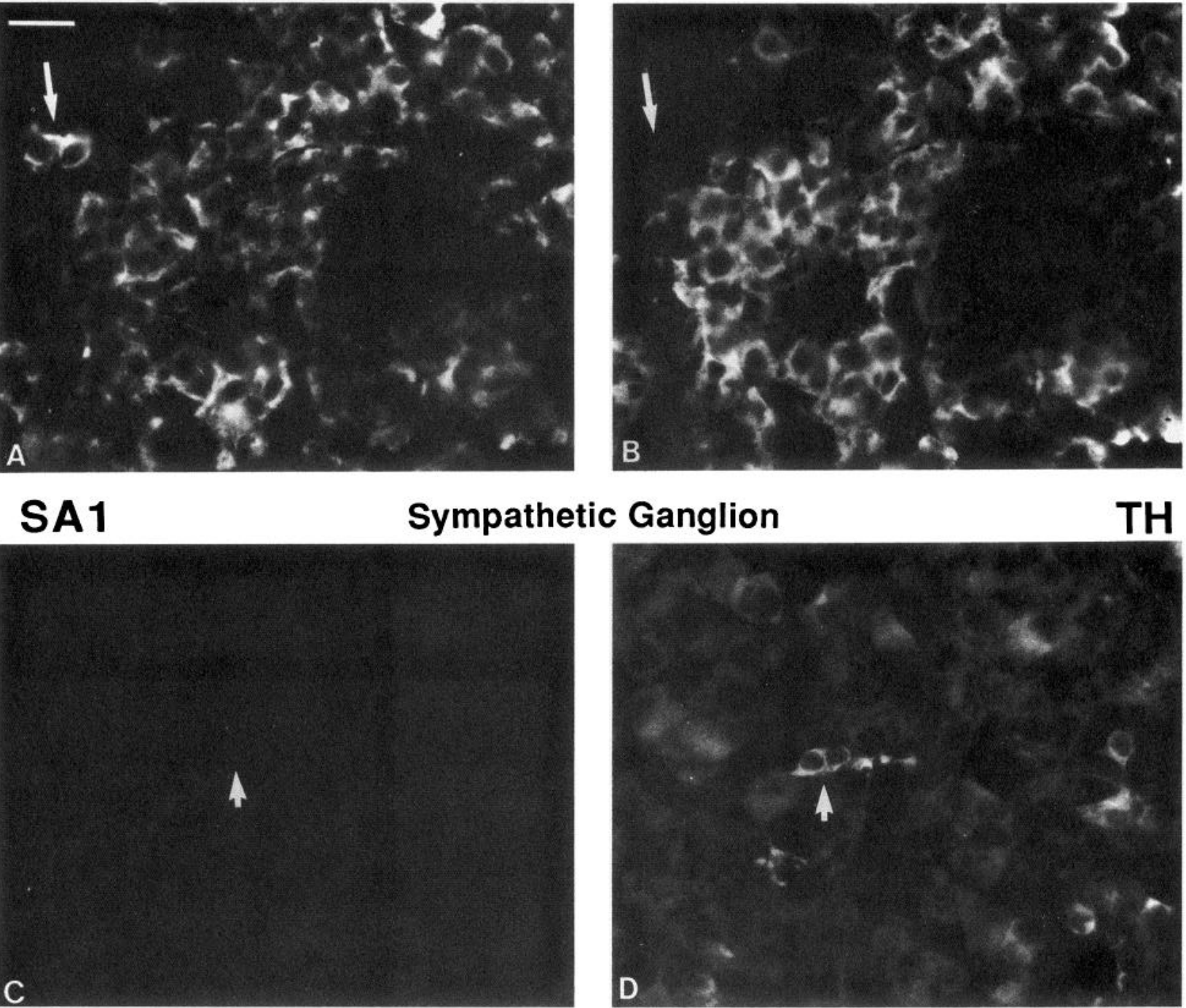

TH

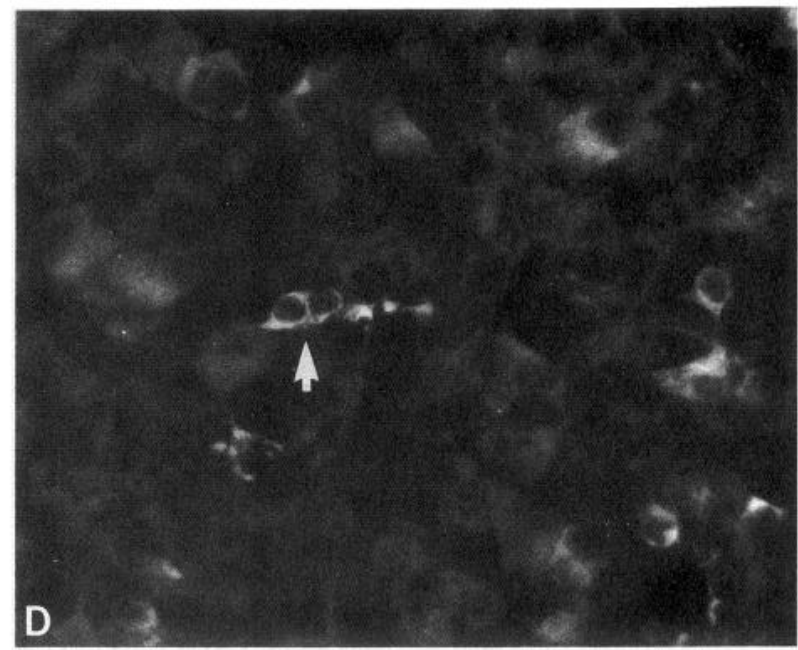

Figure 1. SA1 discriminates between the cells of neonatal sympathetic ganglia and adrenal chromaffin cells. Frozen sections of neonatal rat adrenal gland were double labeled for SA1 $(A)$ and PNMT $(B)$, and sections of neonatal SCG were double stained for SA1 $(C)$ and TH $(D)$. Neurons and glia do not express detectable levels of the SA1 antigen, while chromaffin cells are positive. Arrows in $A$ and $B$ show that even the small population of PNMT-chromaffin cells express SA1. In other experiments, the identity of such chromaffin cells was confirmed by double staining for TH. Most SIF cells ( $C$ and $D$, arrows) are negative for SA1. Scale bar, $27 \mu \mathrm{m}$.

ential staining with SA1-5 is illustrated in Figures 1 and 2. Double staining with SAl and PNMT confirmed the staining of chromaffin cells in the adrenal medulla (Fig. 1). About $80 \%$ of rat adrenal chromaffin cells express PNMT (Unsicker et al., 1978a; Bohn et al., 1981; Verhofstad et al., 1985; Coupland and Tomlinson, 1989), and SA1-5 bind the PNMT- ${ }^{-}$cells as well as the clusters of $\mathrm{PNMT}^{+}$cells (Fig. 1 $A, B$, arrows). Since no SA binding is observed in areas of the adrenal that are clearly cortex, and since all $\mathrm{SA}^{+}$cells also express TH (Figs. 4, 5), the PNMTcells stained by the SA antibodies are very likely norepinephrine-containing adrenal chromaffin cells.

Double staining of adult sympathetic ganglia with SA1-5 and TH revealed that not only were the SA antibodies negative for neurons, but they also did not appear to bind to SIF cells in these ganglia (Fig. 1C,D). The latter were visualized by their high TH levels. All four panels in Figure 1 were exposed and developed comparably.
Loss of SA expression in developing sympathetic ganglia

Using the HNK-1 antibody to visualize neural crest cells at embryonic day 9 (E9) and E10 (Erickson et al., 1989), SA1-5 exhibited no detectable binding to migrating crest cells (Fig. 3). By E11.5, the stage when TH begins to be expressed (Cochard et al., 1979), each of the SA antibodies appears to bind to all $\mathrm{TH}^{+}$cells in the SCG (Fig. 4A). Since each of the SA antibodies displayed strong cytoplasmic staining of the embryonic ganglion, the distribution of SA1 serves as an example of the set. SA15 staining of sympathetic ganglia declines rapidly with further development (Fig. 4C,E). Double labeling of dissociated cell suspensions with TH and SA1 indicates that by E16.5, only 25$30 \%$ of the $\mathrm{TH}^{+}$cells are SA1 ${ }^{+}$(see also Carnahan and Patterson, 1991). Those cells in neonatal ganglia that are still SA1+ are also the cells most strongly positive for TH staining, while the weakly $\mathrm{TH}^{+}$cells were most often $\mathrm{SA}^{-}$(Fig. $4 E, F$, arrows). That is, the 

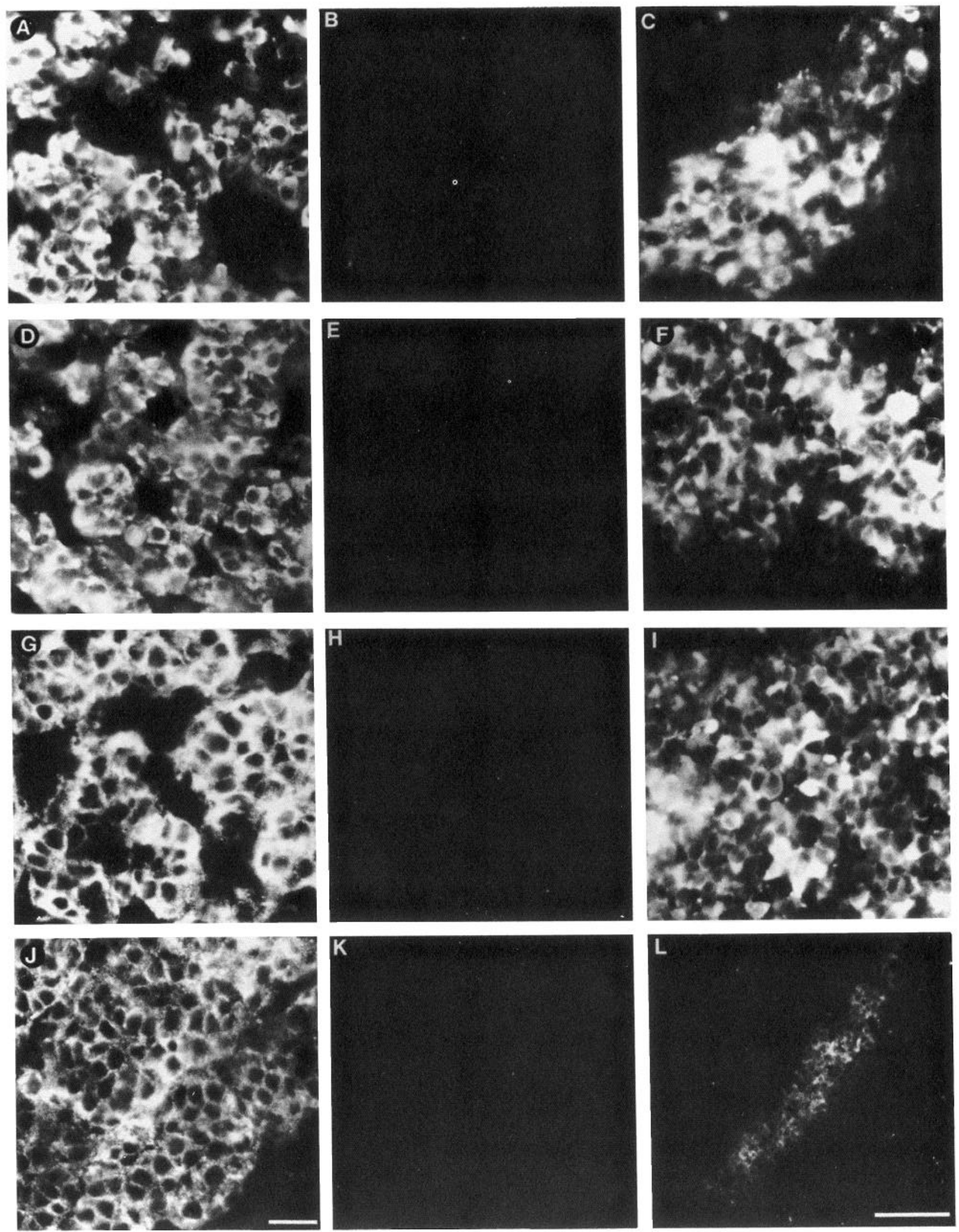

Figure 2. SA2-5 also selectively bind embryonic sympathetic ganglia and adrenal chromaffin cells. Frozen sections of neonatal rat adrenal gland (left column), neonatal sympathetic ganglia (middle column), and E12.5 sympathetic ganglia (right column) were stained with SA2 ( $A-C$ ), SA3 ( $D-$ $F)$, SA4 $(G-I)$, and SA5 $(J-L)$. Scale bar: $J, 25 \mu \mathrm{m}$ for $A-K ; L, 100 \mu \mathrm{m}$. 


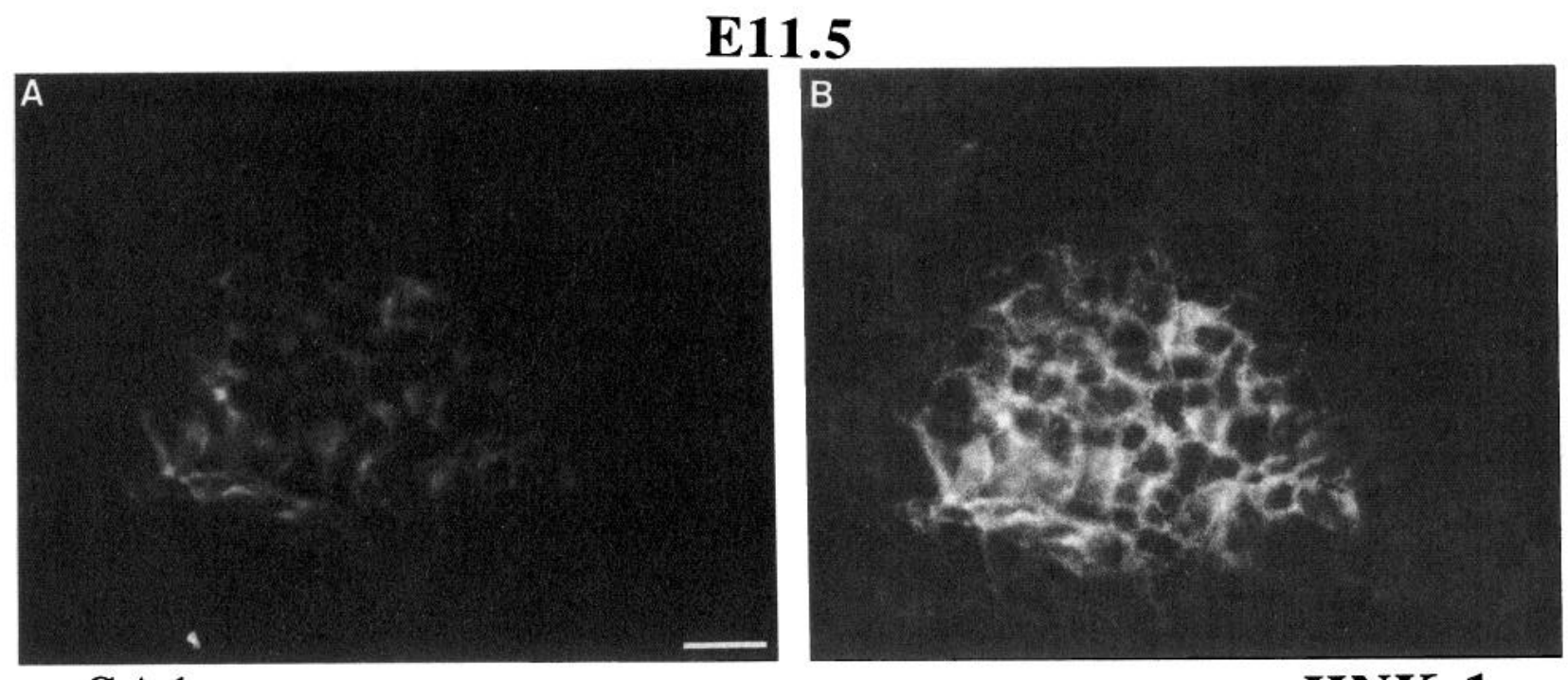

\section{SA1}

E10.5

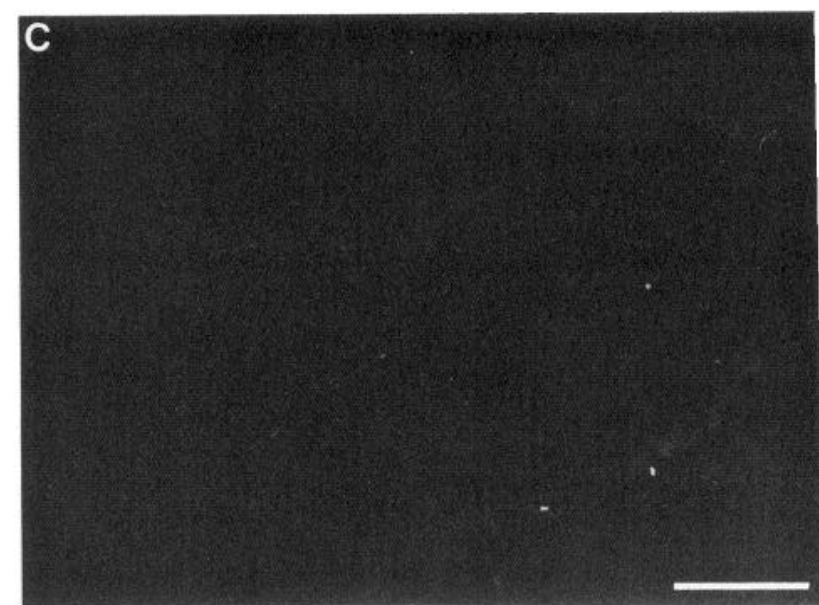

SA1

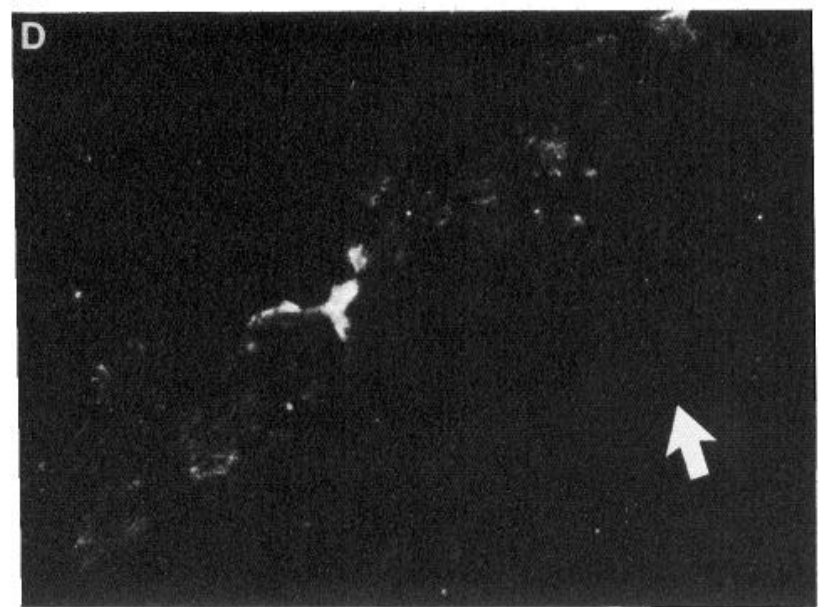

HNK-1

Figure 3. SA1 is not detected in migrating neural crest cells. Serial sections through E9-11.5 embryos were stained for HNK-1 and SA1. At E11.5, $\mathrm{SA} 1$ stains the brightest $\mathrm{HNK}^{+}$cells in sympathetic ganglia $(A, B)$. No SAl staining was detected at E10.5, however $(C)$. These sections were double stained with HNK to visualize migrating neural crest cells $(D)$. The arrow points out the somites cut in longitudinal section. Scale bars: $A, 44 \mu \mathrm{m}$; $C, 76 \mu \mathrm{m}$.

last cells to lose SA staining are those that express $\mathrm{TH}$ most strongly (see also Anderson et al., 1991). These are most likely SIF cells (Jacobowitz, 1970; Unsicker et al., 1978a; Taxi, 1979; El-Maghraby and Lever, 1980). Since SIF cells in adult SCG are $\mathrm{SA}^{-}$(Fig. $\left.1 C, D\right)$, these results indicate that SIF cells undergo postnatal maturation.

\section{Adrenal chromaffin cells maintain SA1-5 expression}

The developmental profile of SA1-5 staining in the adrenal medulla is quite different from that in sympathetic ganglia. In the embryonic adrenal, SA1-5 staining is detectable as the precursors migrate into the anlage (Fig. $5 A$ ), and it is maintained through adulthood (Figs. 1, 5C,E). There is a good correlation between TH and SA staining at all ages in the medulla (Fig. 5). In the extraadrenal chromaffin body, adjacent to the adrenal (* in Fig. $5 A$ ), $\mathrm{TH}^{+}$cells lose SA1 staining early in development, as in sympathetic ganglia.

\section{SA expression in other areas of the nervous system}

While SA binding is correlated with high TH staining, the association is not absolute. That is, $\mathrm{TH}^{+}$cells in tissues that are not members of the SA lineage can be SA1-5- For example, a subpopulation of neurons in the rat nodose ganglion are strongly stained for TH (Katz et al., 1983; Katz and Black, 1986; Katz and Erb, 1990), but at no stage are these sensory neurons SA ${ }^{+}$ (Fig. $6 A$ ). The $\mathrm{TH}^{+}$nodose neurons also do not appear to express the SAl epitope in culture (D. Katz, personal communication). Cells of the carotid body are likewise known to contain high levels of TH (Biscoe, 1971; Pearse et al., 1973; Hansen and Christie, 1981), and these cells are also negative for SA1 from E15.5 through adulthood (Fig. 6C). Finally, a subpopulation of sensory neurons in embryonic dorsal root ganglia have been shown to express TH transiently (Jonakait et al., 1984, 1985), and $\mathrm{SA}^{+}$cells were not detected in these ganglia (Fig. $6 E$ ). SA1 


\section{SA1}
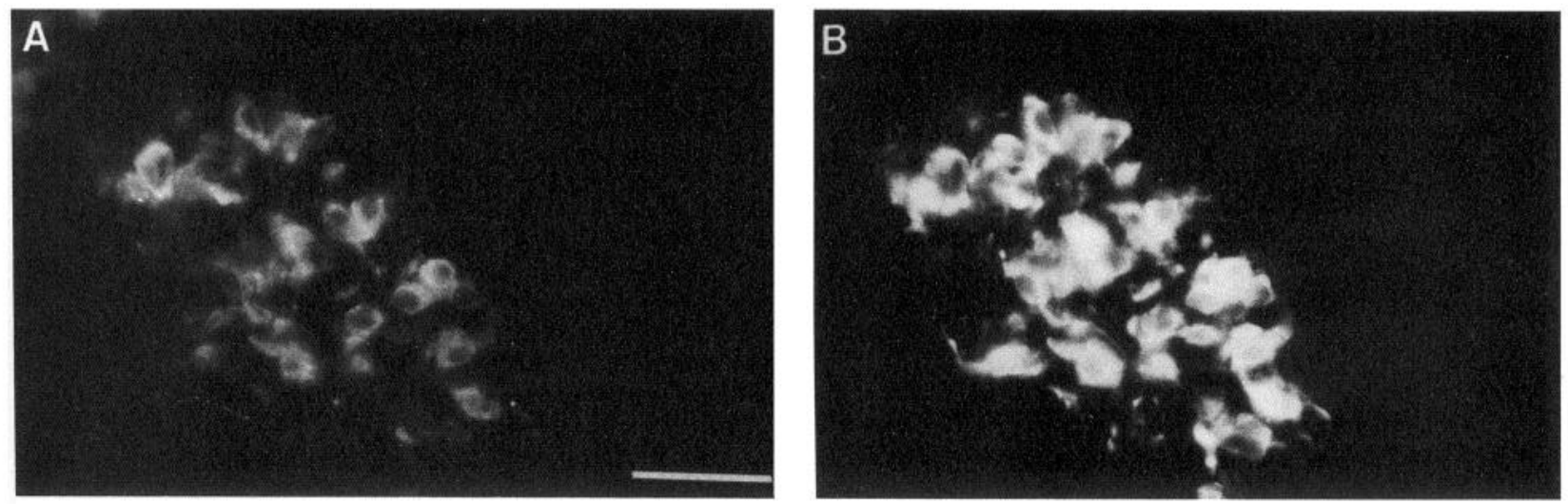

E11.5
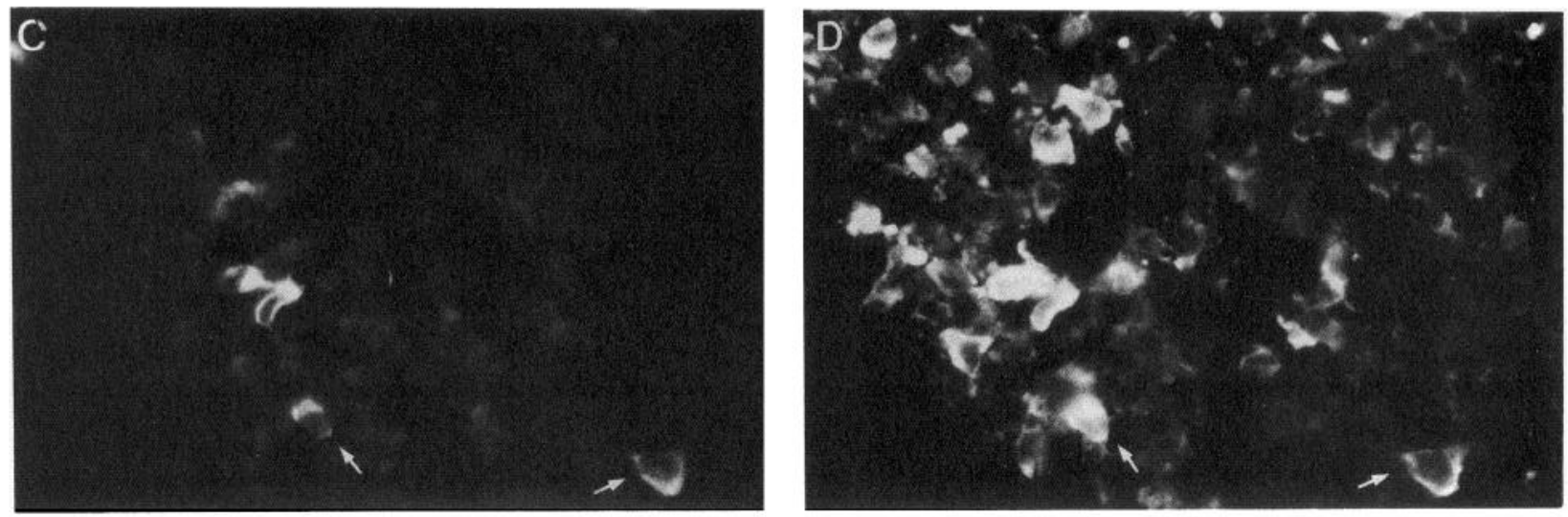

E14.5
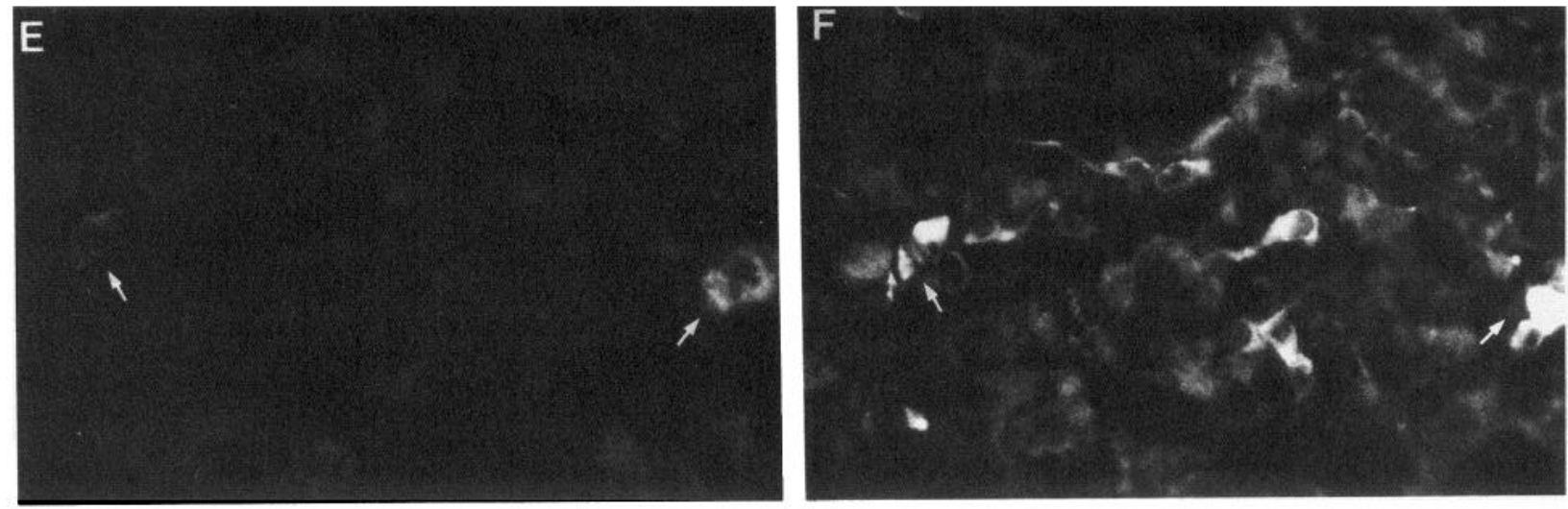

\section{PO}

Figure 4. SA1 is transiently expressed in sympathetic ganglia. Sections of sympathetic ganglia were double stained at E11.5 $(A, B)$, E14.5 $(C, D)$, and at birth $(\mathrm{P} 0 ; E, F)$ for SA1 $(A, C, E)$ and TH $(B, D, F)$. Arrows denote brightly TH-stained cells that have not yet ceased SAl expression; most neonatal SIF cells are, however, $\mathrm{SA}^{-}$. Scale bar, $42 \mu \mathrm{m}$.

staining was also not detected in embryonic or neonatal rat brain (data not shown). SA1 does, however, bind to the transiently $\mathrm{TH}^{+}$neurons of the embryonic gut (Carnahan et al., 1991).

The immunohistochemical results are summarized in $\mathrm{Ta}$ ble 2 .

\section{Discrimination of the $S A$ epitopes}

Since the tissue distribution and developmental time course of all five SA antibodies are the same, it was possible that these antibodies all bind to the same epitope. There are, however, 


\section{SA1}

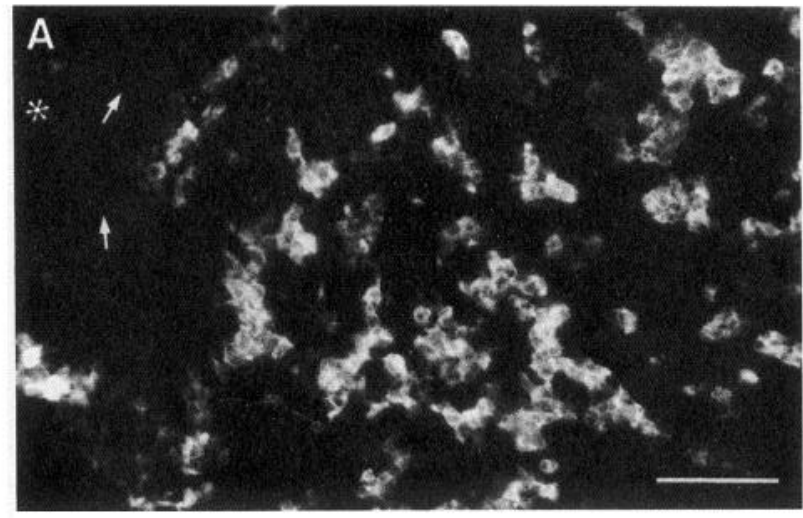

TH

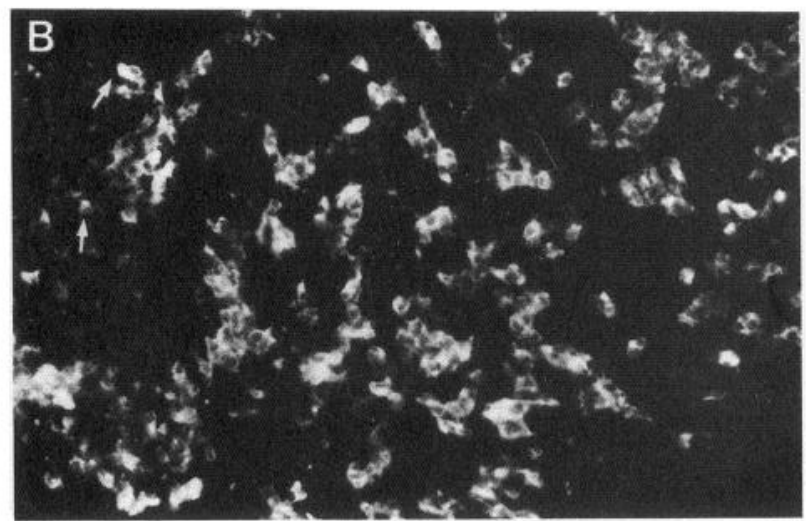

E15.5
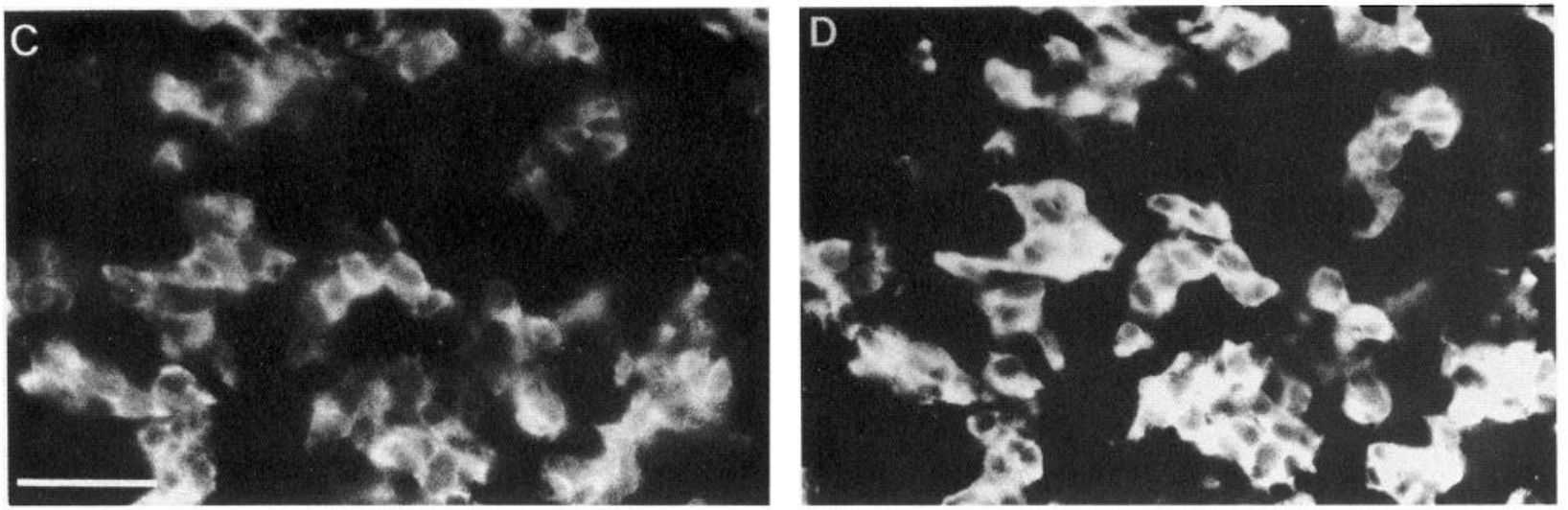

E15.5
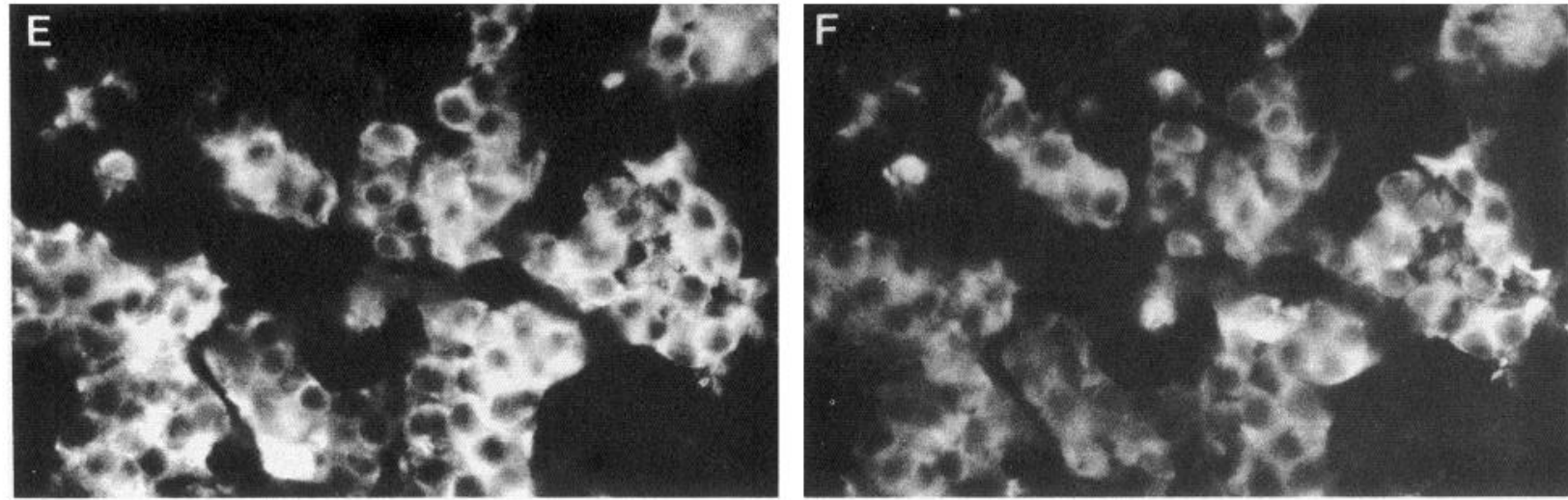

PO

Figure 5. SA1 expression continues in adrenal chromaffin cells throughout development. Sections of the adrenal gland at E15.5 (A-D) and at birth $(E, F)$ were double stained for SAl and TH. A very strong correlation between the two markers is observed in the adrenal gland. In contrast, some brightly $\mathrm{TH}^{+}$cells in the extraadrenal chromaffin body ( ${ }^{*}$ in $A$; arrows) have ceased SAl expression. Scale bars: $A, 100 \mu \mathrm{m}$ for $A$ and $B$; $C$, $40 \mu \mathrm{m}$ for $C-F$.

differences in the subcellular localization of the binding of some of the antibodies. For instance, when E18.5 adrenal chromaffin cells are freshly dissociated and surface stained (without fixation and permeabilization), the following percentages of cells are positive for each of the antibodies: SA1, 74\%; SA2, 77\%; SA3, $9 \%$; SA4, 53\%; SA5, $13 \%$. When these cells are permeabilized, however, each of the antibodies binds to all of the $\mathrm{TH}^{+}$cells.
Thus, while each antibody binds well to the cytoplasmic antigen(s), the antibodies display striking differences in their recognition of surface epitopes. In addition, only SA1 binds well to fixed and permeabilized chromaffin cells in culture (see Fig. 8). Differences in the fixation sensitivity of the epitopes in tissue sections are also apparent (data not shown). Taken together, these findings suggested the possibility that SAl-5 could be 

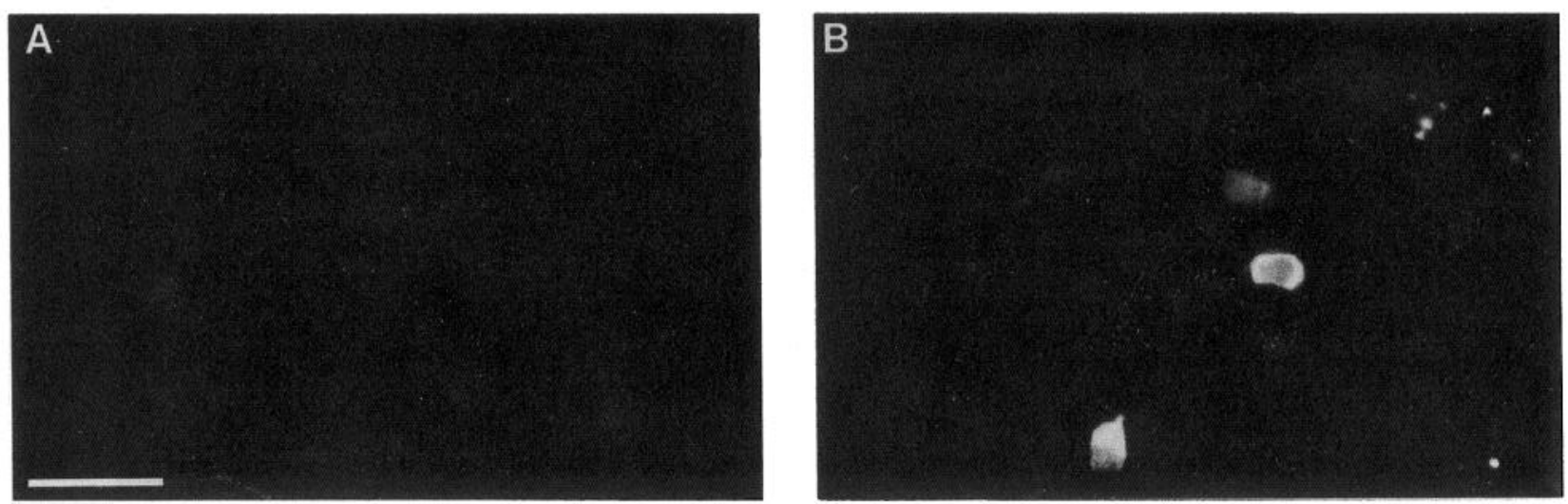

SA1

E17.5 Nodose

TH
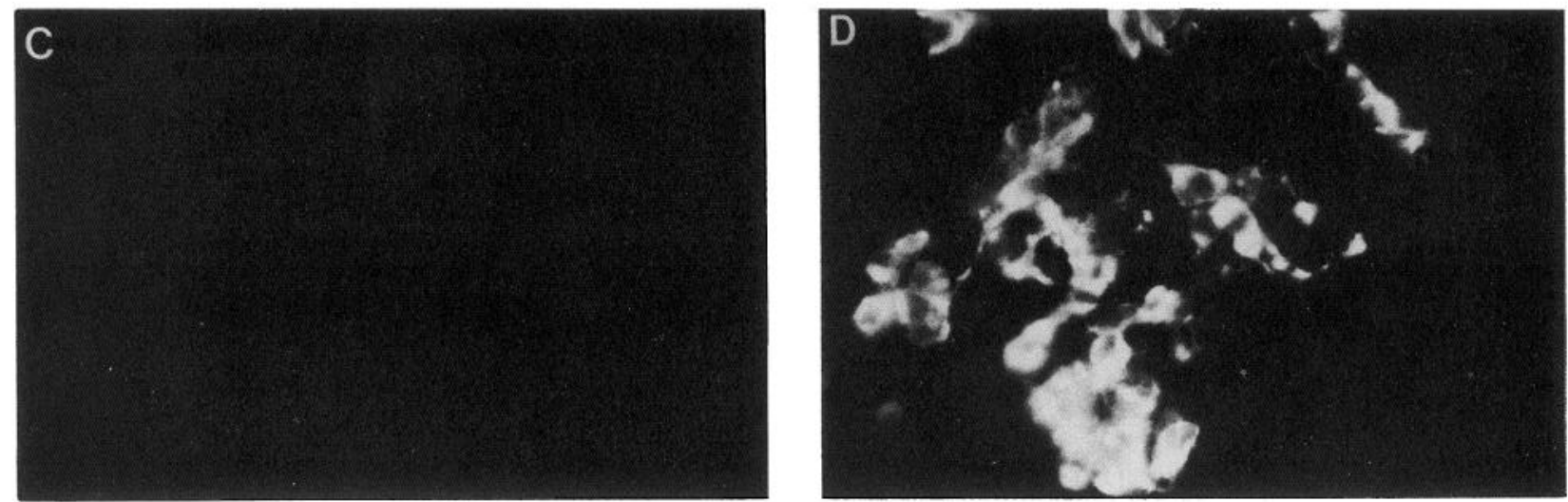

SA1

E18.5 Carotid Body

TH
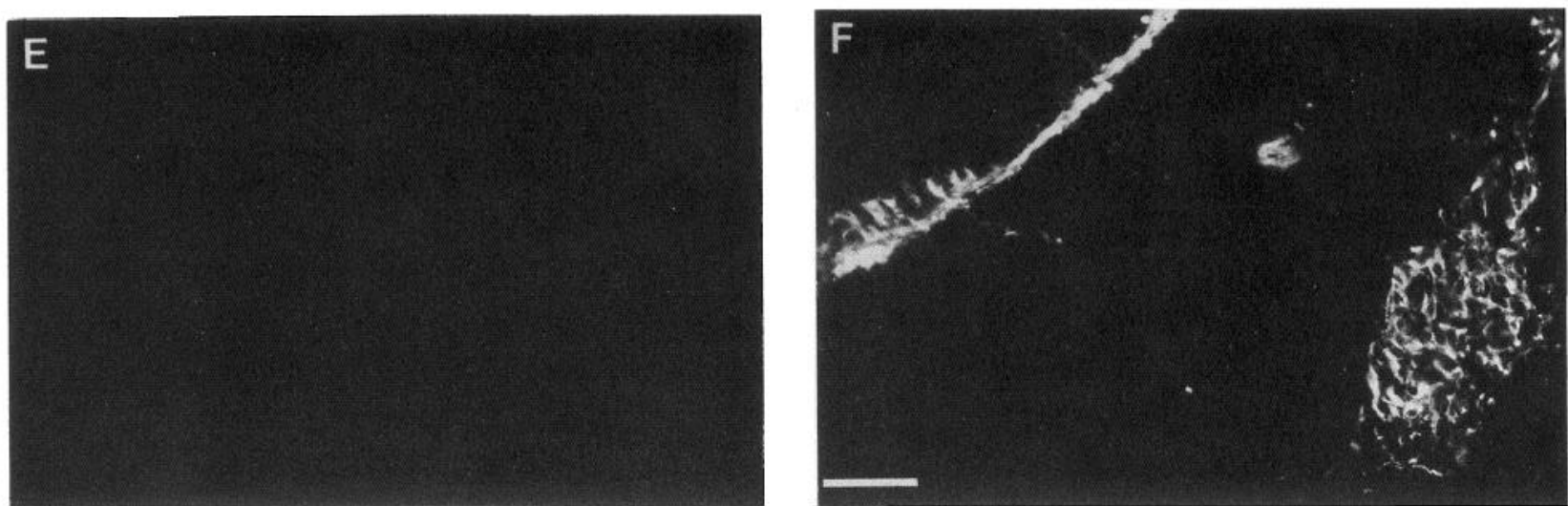

SA1

E11.5 DRG

NF

Figure 6. $\mathrm{TH}^{+}$cells in other ganglia do not express detectable $\mathrm{SA} 1$ antigen. Sections of nodose ganglia $(A, B)$ and carotid body $(C, D)$ were double stained with SA1 and TH. Sections of dorsal root ganglia $(D R G ; E, F)$ were double stained with SA1 and NF. No SAl staining was detectable in these ganglia at any stage of development. Scale bars: $A, 40 \mu \mathrm{m}$ for $A-D ; F, 70 \mu \mathrm{m}$ for $E$ and $F$.

binding to several different epitopes on the same antigen, or to different antigens that exhibit very similar specificities of expression.

To test further the possibility that some of the SA antibodies bind distinct epitopes, we performed a competition experiment, using immunohistochemistry of neonatal adrenal gland sections as the assay. The SA2 antibody was directly labeled with biotin and added to the sections at a concentration just sufficient to detect staining of adrenal sections using streptavidin-Texas red. Under the same conditions, sections were incubated with labeled SA2 plus a second, unlabeled, SA antibody (the unlabeled antibody was added at a supramaximal concentration for staining by itself). SA2 staining was compared with and without competing antibodies. A positive control for competition is the addition of unlabeled SA2 antibody, which completely abolishes staining (Fig. $7 F$ ). Three antibodies (SA1, -4, -5) did not di- 

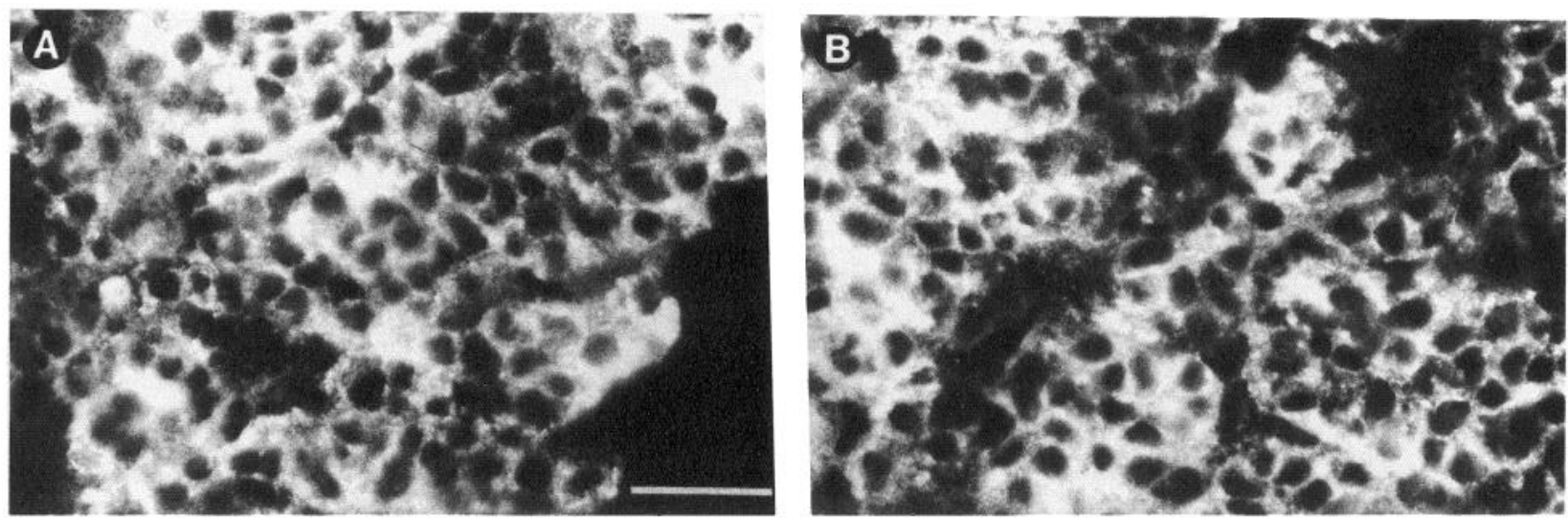

\section{NO COMPETITION}
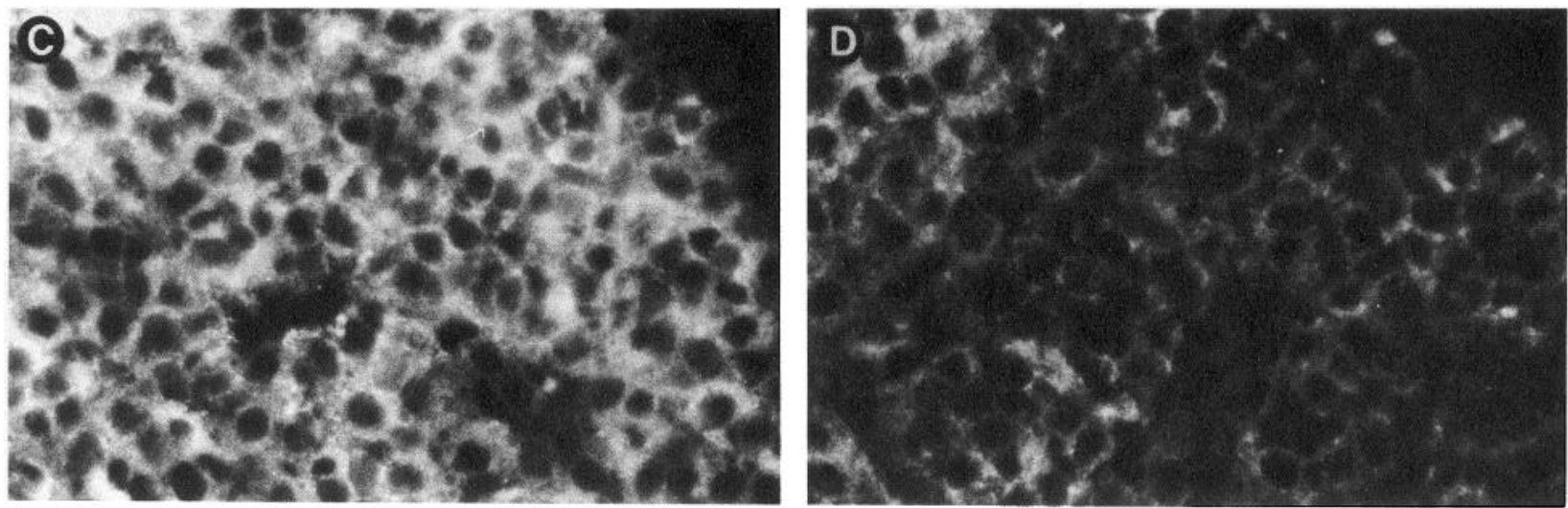

PARTIAL COMPETITION
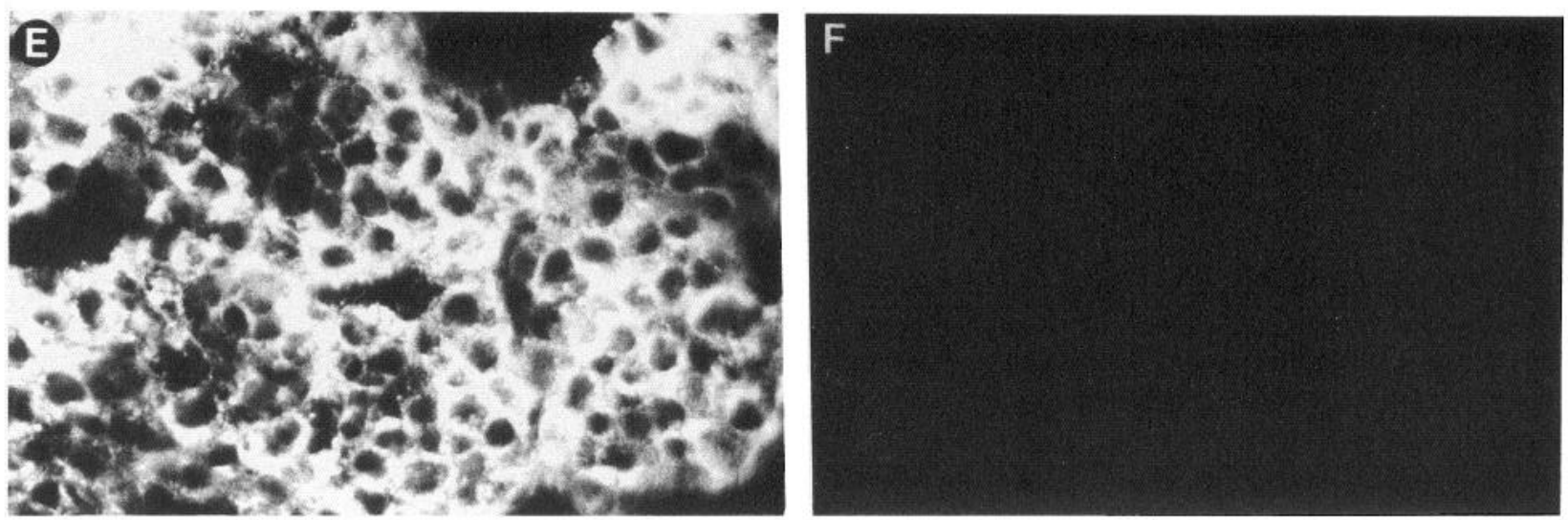

\section{COMPLETE COMPETITION}

Figure 7. Competition between the SA antibodies indicates at least three discrete epitopes on sections. Sections of adrenal medulla were incubated with biotin-labeled SA2 antibody alone $(A, C, E)$ or simultaneously with an unlabeled antibody $(B, D, F)$. Coincubation with SA1 did not diminish SA2 staining $(A, B)$; the same result was obtained with SA4 and -5 and a control anti-Thy- 1 antibody (data not shown). Coincubation with SA3 resulted in a partial inhibition of SA2 staining $(C, D)$. Coincubation of unlabeled SA2 with the labeled SA2 abolished staining $(E, F)$. These results imply the existence of at least three distinct epitopes: SA2; SA1,4,5; and SA3. Scale bar, $40 \mu \mathrm{m}$.

minish SA2 staining (Fig. 7B), while SA3 showed partial inhibition of SA2 binding (Fig. 7D). Addition of an anti-Thy-1 antibody as a negative control also did not inhibit SA2 staining (data not shown).

Since all five SA antibodies stain adrenal sections equally brightly at the concentrations used in the competition experiment, the lack of inhibition by some antibodies implies that there are at least three different epitopes recognized by the SA antibodies; one recognized by SA2, one by the partial inhibitor $\mathrm{SA} 3$, and the site(s) recognized by $\mathrm{SA} 1,-4$, and -5 . Further evidence for multiple epitopes is the finding that a mixture of at least three different SA antibodies was necessary to visualize cell surface staining in early (E14.5) sympathetic ganglia (Carnahan and Patterson, 1991). That is, addition of single antibodies at saturating concentrations did not yield detectable staining, but the staining of several antibodies simultaneously 
Table 2. Spatial and temporal distribution of SA expression

\begin{tabular}{llll} 
& Embryo & Neonate & Adult \\
\hline SCG & ++ & - & - \\
AM & ++ & ++ & ++ \\
DRG & - & - & - \\
Nodose & - & - & - \\
Brain & - & - & ND \\
Carotid body & - & - & - \\
\hline
\end{tabular}

Summary of immunohistochemical distribution of SA1-5 straining of various tissues at three ages. Embryo refers to E12-18. AM, adrenal medulla; DRG, dorsal root ganglion. -, no detectable binding; ND, not done.

is additive. Such additivity would not be expected if all antibodies bound to the same epitope. Finally, as mentioned above, only one of the antibodies, SAl, stains cultured adrenal chromaffin cells (Fig. 8 and data not shown), suggesting that the SA1 epitope is different from those of SA2-5. Thus, the three antibodies that could not be distinguished from one another in the competition experiment can be divided into two groups, SA1 and SA4 and -5 . Thus, there appear to be at least four different epitopes recognized by this set of antibodies, all with the same cellular specificity.

Attempts to identify the SA antigen(s) by Western blotting and immunoprecipitation methods have thus far proved negative.

\section{Regulation of $S A I$ antigen expression}

As mentioned above, SAl stains the cytoplasm and cell surface of adrenal chromaffin cells in culture. Taking advantage of this property, we examined the influence of glucocorticoid and NGF on the expression of the SA1 antigen. Glucocorticoid is required for the survival of rat adrenal chromaffin cells and for the maintenance of their differentiated characteristics (Doupe et al., 1985a). This hormonal condition mimics the environment of the adrenal medulla. In the presence of the synthetic glucocorticoid dexamethasone, SAl staining is maintained on the chromaffin cells indefinitely (Fig. $8 A$ ). On the other hand, when glucocorticoid is removed and NGF added to the cells, they undergo a conversion to the neuronal phenotype (Fig. $8 F$ ) (Unsicker et al., 1978; Doupe et al., 1985a; Unsicker and Lietzke, 1987). NGF diminishes the staining of these cells by SA1, beginning as soon as $24 \mathrm{hr}$ of incubation (Fig. $8 \mathrm{~B}$ ). Upon removal of dexamethasone and in absence of added NGF, cells were still $\mathrm{SA}^{+}$, but its expression was weaker compared to cultures grown in dexamethasone (data not shown).

\section{Discussion}

Our goal in this project was to generate monoclonal antibodies against the surfaces of the progenitor cells of the SA lineage. Such antibodies could potentially be used to isolate the precursors by cell sorting, as well as to follow the development of these cells in vivo. Since we did not have a method for isolating significant numbers of these cclls to usc as an enriched source of antigen, we took advantage of the known similarities between adrenal chromaffin cells, SIF cells, and the presumed SA precursors (Landis and Patterson, 1981; Doupe et al., 1985a,b; Anderson and Axel, 1986). Thus, we used neonatal rat adrenal medullae as the source of antigen and employed the cyclophosphamide immunosuppression method to lessen greatly the frequency of generating antibodies against antigens shared between chromaffin cells and other cell types. This technique es- sentially tolerizes the mice against common antigens and enhances the frequency of obtaining antibodies against rare or nonimmunogenic antigens (Matthew and Patterson, 1983; Matthew and Sandrock, 1987; Suzue et al., 1990; Ou et al., 1991). The results presented in Table 1 confirm the utility of this approach, as a significant number of antibodies were generated with the desired specificity.

Studies on phenotypic decision making within a given lineage rcquirc markers selective for each stage where new derivatives are generated. When multipotential neural crest cells differentiate into committed SA progenitor cells, TH is a very useful label because it designates cells that have taken the earliest known differentiated step in this pathway. TH and catecholamine histofluorescence are expressed while the early SA cells are still dividing (Cohen, 1972; Rothman et al., 1978; Rohrer and Thoenen, 1987; Ernsberger et al., 1989). In addition, TH and catecholamine production are ubiquitous markers for all members of the SA group, until transmitter choice is reversed in certain neurons postnatally (Landis and Patterson, 1981; Landis and Keefe, 1983). TH and catecholamines are not, however, restricted to the SA branch of the neural crest lineage. Catecholamines and/or their biosynthetic enzymes are found in early neurons in the gut (Cochard et al., 1978; Teitelman et al., 1981; Jonakait et al., 1985; Baetge and Gershon, 1989), in certain parasympathetic (Börklund et al., 1985; Iacovitti et al., 1985; Landis et al., 1987; Uemura et al., 1987; Leblanc and Landis, 1989) and sensory neurons (Katz et al., 1983; Jonakait et al., 1984; Katz and Black, 1986; Katz and Erb, 1990), as well as in the CNS. There are many other examples of such markers that are quite useful under normal conditions, particularly in situ, but that cannot be used as absolute markers of a developmental stage or subpopulation of cells. Other examples include the neuropeptides; substance $P$ can be used to identify certain sensory neurons, but other cells can express it in vivo (Bohn et al., 1984) and in vitro (Kessler, 1984; Nawa and Sah, 1990).

The SA antibodies label the early SA cells defined by TH and catecholamine histofluorescence, but SA expression becomes much more restricted in its distribution than the latter markers. Moreover, unlike TH, SAI was not detected in the CNS, nor in the sensory or parasympathetic ganglia that have been studied thus far. SA expression is also different from TH and catecholamines in that it is not found in all members of the SA pathway but rather is maintained primarily in adrenal chromaffin cells. Previous chromaffin cell markers included the very large size of chromaffin vesicles as visualized by electron microscopy (ElMaghraby and Lever, 1980), and the enzyme PNMT, present in a subpopulation of chromaffin cells.

The SA antibodies can also be used to detect the embryonic progenitor cells that give rise to the SA lineage. This is suggested 


\section{DEX}

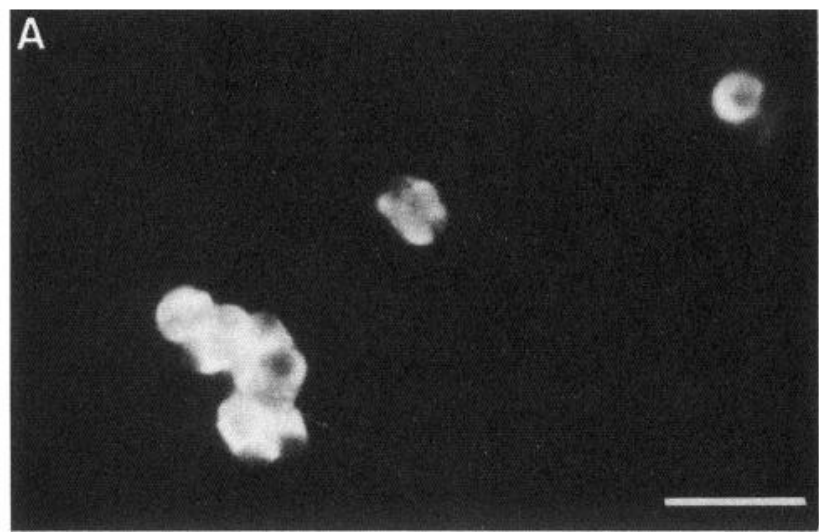

SA1

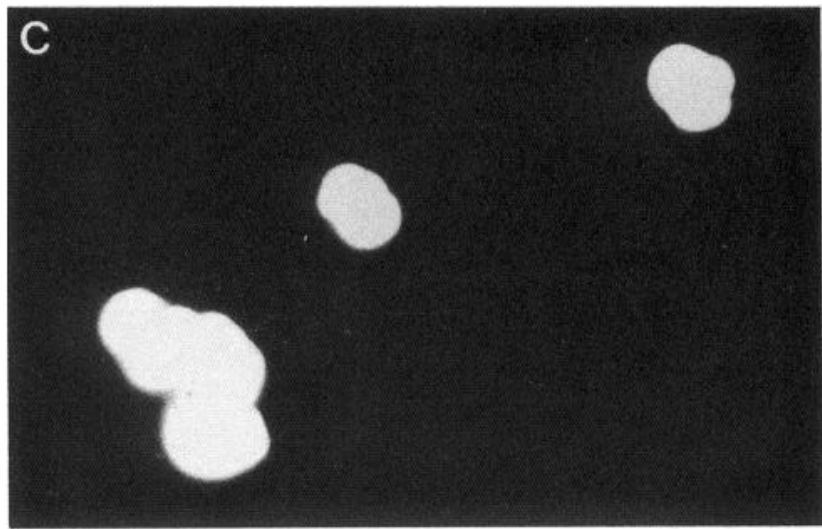

TH

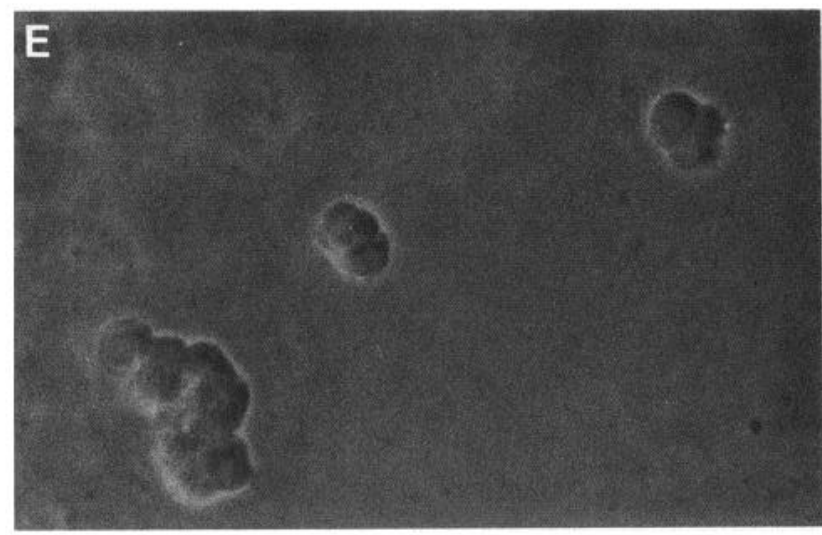

phase
NGF

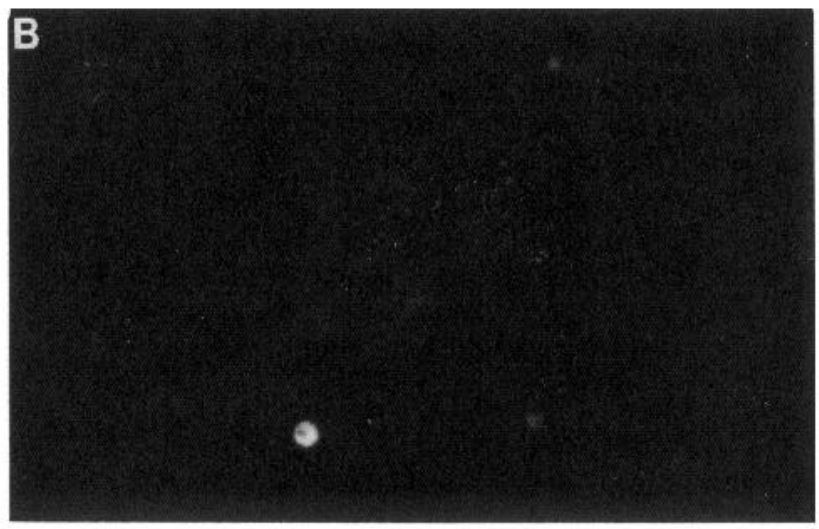

SA1

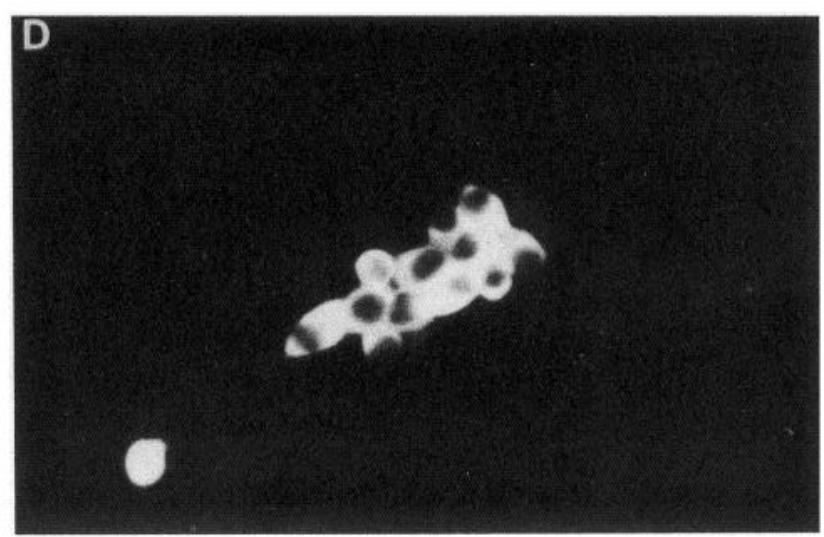

TH

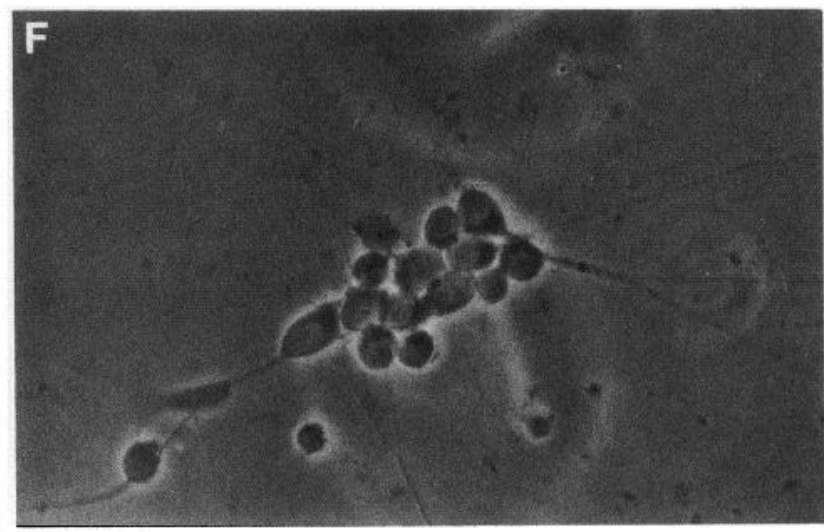

phase

Figure 8. SAl expression in cultured neonatal adrenal chromaffin cells is regulated by glucocorticoid and NGF. Chromaffin cells from neonatal rats were cultured in the presence of dexamethasone $(D E X ; A, C, E)$ or NGF $(B, D, F)$. After $4 \mathrm{~d}$, the cells were double stained for SAl $(A, B)$ and TH $(C, D)$. Neurite extension is apparent in the presence of NGF $(F)$ but not in dexamethasone $(E)$. The bright cell in $B$ is a nonspecifically stained dead cell. Scale bar, $40 \mu \mathrm{m}$.

by the observations that (1) SA1 labels the same cells in the early ganglion primordium as does TH (another, independent, SA lineage marker), (2) ganglionic cells isolated by virtue of their SA1-5 antigen expression can give rise to either chromaffin cells or neurons in culture (Carnahan and Patterson, 1991), and
(3) $\mathrm{SA}^{+}$cells initially coexpress neuron-specific markers in embryonic sympathetic ganglia, implying the existence of transiently dual-phenotype progenitor cells in vivo (Anderson et al., 1991). In these respects, the SA antibodies are reminiscent of the antibodies that bind to certain cholinergic, parasympathetic 
neurons and were used to select a subpopulation of neural crest cells that give rise to these neurons (Barald, 1988).

What is the function of the antigen(s) that the SA antibodies recognize? Since the epitopes are restricted to cells producing catecholamines, they could play a role in the synthesis, storage, breakdown, or release of these transmitters. The epitopes are unlikely, however, to be part of a previously studied component of these systems bccausc they arc not detceted in sympathetic neurons or in other noradrenergic neurons. The SA antigen(s) is also unlikely to be PNMT because (1) SA1 is expressed in PNMT- chromaffin cells, (2) PNMT is cytoplasmic while SA1 becomes a surface antigen, and (3) PNMT appears much later in development than does the SA antigen(s) (Bohn, 1986). The $\mathrm{SA}$ antigen(s) is found in both the cytoplasm and on the cell surface, although it appears first in development in the former site and only later accumulates on the cell surface (Carnahan and Patterson, 1991). This subcellular distribution is not that expected for synaptic vesicle membrane components; these appear on the cell surface only transiently, during periods of intense stimulation and transmitter release (Winkler et al., 1986). In addition, the observation that cell surface labeling at early times requires the addition of three SA antibodies simultaneously, while requiring only one antibody later (Carnahan and Patterson, 1991), suggests that the antigen(s) is being added to the surface membrane slowly, over time.

\section{References}

Agius MA, Richman DP (1986) Suppression of development of experimental autoimmune myasthenia with isogeneic monoclonal antiidiotopic antibody. J Immunol 137:2195-2198.

Aloe L, Levi-Montalcini R (1979) Nerve growth factor-induced transformation of immature chromaffin cells in vivo into sympathetic neurons: effect of antiserum to nerve growth factor. Proc Natl Acad Sci USA $76: 1246-1250$.

Anderson DJ (1989) The neural crest cell lineage problem: neuropoiesis? Neuron 3:1-12.

Anderson DJ, Axcl R (1986) A bipotential ncuroendocrinc precursor whose choice of cell fate is determined by NGF and glucocorticoids. Cell 47:1079-1090.

Anderson DJ, Carnahan JF, Michelsohn A, Patterson PH (1991) Antibody markers identify a common progenitor to sympathetic neurons and chromaffin cells in vivo and reveal the timing of commitment to neuronal differentiation in the sympathoadrenal lineage. J Neurosci 11:3507-3519.

Baetge G, Gershon MD (1989) Transient catecholaminergic (TC) cells in the vagus nerves and bowel of fetal mice: relationship to the development of enteric neurons. Dev Biol 132:189-211.

Barald KF (1988) Monoclonal antibodies made to chick mesencephalic neural crest cells and to ciliary ganglion neurons identify a common antigen on the neurons and a neural crest subpopulation. $J$ Neurosci Res 21:107-118.

Barald KF, Wessels NK (1984) Differential antigen adhesivity used to select spleen cells for the production of monoclonal antibodies to embryonic neurons. J Immunol Methods 73:1-15.

Barclay SL, Smith AM (1986) Rapid isolation of monoclonal antibodies specific for cell surface differentiation antigen. Proc Natl Acad Sci USA 83:4336-4340.

Birren SJ, Anderson DJ (1990) A v-myc-immortalized sympathoadrenal progenitor cell line in which neuronal differentiation is initiated by FGF but not NGF. Neuron 4:189-201.

Biscoe TJ (1971) Carotid body: structure and function. Physiol Rev $51: 437-495$.

Bohn MC (1986) Expression and development of phenylethanolamine $N$-methyltransferase (PNMT): role of glucocorticoids. In: Neurohistochemistry: modern methods and applications, pp 245-271. New York: Liss.

Bohn MC, Goldstein M, Black IB (1981) Role of glucocorticoids in expression of the adrenergic phenotype in rat embryonic adrenal gland. Dev Biol 82:1-10.
Bohn MC, Kessler JK, Adler JE, Markey K, Goldstein M, Black IB (1984) Simultaneous expression of the SP-peptidergic and noradrenergic phenotypes in rat sympathetic neurons. Brain Res 298:378381.

Börklund H, Hökfelt T, Goldstein M, Terenius L, Olson L (1985) Appearance of the noradrenergic markers tyrosine hydroxylase and neuropeptide $\mathrm{Y}$ in cholinergic nerves of the iris following sympathectomy. J Neurosci 5:1633-1643.

Carnahan J, Patterson PH (1988) Markers for the early sympathoadrenal lineage. Soc Neurosci Abstr 14:132.1.

Carnahan JF, Patterson PH (1991) Isolation of the progenitor cells of the sympathoadrenal lineage from embryonic sympathetic ganglia with the SA monoclonal antibodies. J Neurosci 11:3520-3530.

Carnahan JF, Anderson DJ, Patterson PH (1991) Evidence that enteric neurons may derive from the sympathoadrenal lineage. Dev Biol, in press.

Chaudhary VK, Batra JK, Gallo MG, Willingham MC, FitzGerald DJ, Pastan I (1990) A rapid method of cloning functional variable-region antibody genes in $E$. coli as single-chain immunotoxins. Proc Natl Acad Sci USA 87:1066-1070.

Claude P, Parada IM, Gordon KA, D'Amore P, Wagner JA (1988) Acidic fibroblast growth factor stimulates adrenal chromaffin cells to proliferate and to extend neurites, but is not a long-term survival factor. Neuron 1:783-790.

Cochard P, Goldstein M, Black IB (1978) Ontogenic appearance and disappearance of tyrosine hydroxylase and catecholamines in the rat embryo. Proc Natl Acad Sci USA 75:2986-2990.

Cochard P, Goldstein M, Black IB (1979) Initial development of the noradrenergic phenotype in autonomic neuroblasts of the rat embryo in vivo. Dev Biol 71:100-114.

Cohen AM (1972) Factors directing the expression of sympathetic nerve traits in cells of neural crest origin. J Exp Zool 179:167-182.

Coupland RE, Tomlinson A (1989) The development and maturation of adrenal medullary chromaffin cells of the rat in vivo: a descriptive and quantitative study. Int J Dev Neurosci 7:419-438.

Doupe AJ, Landis SC, Patterson PH (1985a) Environmental influences in the development of neural crest derivatives: glucocorticoids, growth factors, and chromaffin cell plasticity. J Neurosci 5:2119-2142.

Doupe AJ, Patterson PH, Landis SC (1985b) Small intensely fluorescent (SIF) cells in culture: role of glucocorticoids and growth factors in their development and phentypic interconversions with other neural crest derivatives. J Neurosci 5:2143-2160.

Drägcr UC, Edwards DL, Klcinschmidt J (1983) Neurofilaments contain $\alpha$-melanocyte-stimulating hormone ( $\alpha$-MSH)-like immunoreactivity. Proc Natl Acad Sci USA 80:6408-6412.

El-Maghraby M, Lever JD (1980) Typification and differentiation of medullary cells in the developing rat adrenal. A histochemical and electron microscopic study. J Anat 131:103-120.

Eränkö L, Eränkö O (1972) Effect of hydrocortisone on histochemically demonstrable catecholamines in the sympathetic ganglia and extra-chromaffin tissue of the rat. Acta Physiol Scand 84:125-133.

Eränkö L, Eränkö O (1977) Developmental aspects of SIF cells. In: Advances in biochemical psychopharmacology (Costa E, Gessa GS, eds), pp 519-524. New York: Raven.

Eränkö O, Eränkö L, Hill CE, Burnstock G (1972) Hydrocortisoneinduced increase in the number of small intensely fluorescent cells and their histochemically demonstrable catccholamine content in cultures of sympathetic ganglia of the newborn rat. Histochem J 4:4958.

Erickson CA, Loring JF, Lester SM (1989) Migratory pathways of HNK-1-immunoreactive neural crest cells in the rat embryo. Dev Biol 134:112-118.

Ernsberger U, Edgar D, Rohrer H (1989) The survival of early chick sympathetic neurons in vitro is dependent on a suitable substrate but independent of NGF. Dev Biol 135:250-262.

Galfre G, Milstein C (1981) Preparation of monoclonal antibodies: strategies and procedures. Methods Enzymol 73:3-46.

Golumbeski GS, Dimond RL (1986) The use of tolerization in the production of monoclonal antibodies against minor antigenic determinants. Anal Biochem 154:373-381.

Ilansen JT, Christie DS (1981) Rat carotid body catecholamincs dctermined by high performance liquid chromatography with electrochemical detection. Life Sci 29:1791-1795.

Hawkes R, Niday N, Gordon J (1982) A dot-immunobinding assay for monoclonal and other antibodies. Anal Biochem 119:142-147. 
Hawrot E, Patterson PH (1979) Long-term culture of dissociated sympathetic neurons. Methods Enzymol 58:574-584.

Hockfield S (1987) A monoclonal antibody to a unique cerebellar neuron generated by immunosuppression and rapid immunization. Science 237:67-70.

Hudson L, Hay FC (1980) Practical immunology, 2d ed. Oxford: Blackwell.

Huse WD, Sastry L, Iverson SA, Kang AS, Alting-Mees M, Burton DR, Benkovic SJ, Lerner RA (1989) Generation of a large combinatorial library of the immunoglobulin repertoire in phage lambda. Science 246:1275-1281.

Iacovitti L, Joh TH, Albert VR, Park DH, Reis DJ, Teitelman G (1985) Partial expression of catecholaminergic traits in cholinergic chick ciliary ganglia: studies in vivo and in vitro. Dev Biol 110:402-412.

Jacobowitz. D (1970) Catecholamine fluorescence studies of adrenergic neurons and chromaffin cells in sympathetic ganglia. Fed Proc Fed Amer Soc Exp Biol 29:1929-1944.

Jacobowitz DM, Greene LA (1974) Histofluorescence study of chromaffin cells in dissociated cell cultures of chick embryo sympathetic ganglia. J Neurobiol 5:65-83.

Johnson GD, de Nogueira Araujo GM (1981) A simple method of reducing the fading of immunofluorescence during microscopy. J Immunol Methods 43:349-350.

Jonakait GM, Markey KA, Goldstein M, Black IB (1984) Transient expression of selected catecholaminergic traits in cranial sensory and dorsal root ganglia of the embryonic rat. Dev Biol 101:51-60.

Jonakait GM, Markey KA, Goldstein M, Dreyfus CF, Black IB (1985) Selective expression of high-affinity uptake of catecholamines by transiently catecholaminergic cells of the rat embryo: studies in vivo and in vitro. Dev Biol 108:6-17.

Katz DM, Black IB (1986) Expression and regulation of catecholaminergic traits in primary sensory neurons: relationship to target innervation in vivo. J Neurosci 6:983-989.

Katz DM, Erb MJ (1990) Developmental regulation of tyrosine hydroxylase expression in primary sensory neurons of the rat. Dev Biol 137:233-242.

Katz DM, Markey KA, Goldstein M, Black IB (1983) Expression of catecholaminergic characteristics by primary sensory neurons in the normal adult rat in vivo. Proc Natl Acad Sci USA 80:3526-3530.

Kessler JA (1984) Non-neuronal cell conditioned medium stimulates peptidergic expression in sympathetic and sensory neurons in vitro. Dev Biol 106:61-69.

Köhler G, Milstein C. (1975) Continuous cultures of fused cells secreting antibody of predefined specificity. Nature 256:495-497.

Landis SC, Keefe D (1983) Evidence for neurotransmitter plasticity in vivo: devclopmental changes in properties of cholinergic sympathetic neurons. Dev Biol 98:349-372.

Landis SC, Patterson SC (1981) Neural crest cell lineages. Trends Neurosci 4:172-175.

Landis SC, Jackson PC, Fredieu JR, Thibault J (1987) Catecholaminergic properties of cholinergic neurons and synapses in adult rat ciliary ganglion. J Neurosci 7:3574-3587.

Leblanc GG, Landis SC (1989) Differentiation of noradrenergic traits in the principal neurons and small intensely fluorescent cells of the parasympathetic sphenopalatine ganglion of the rat. Dev Biol 131: $44-59$.

Le Douarin NM (1982) The neural crest. Cambridge: Cambridge UP.

Mahana W, Guilbert B, Avrameas S (1987) Suppression of anti-DNA antibody production in MRL mice by treatment with anti-idiotypic antibodies. Clin Exp Immunol 70:538-545.

Mains RE, Patterson PH (1973) Primary cultures of dissociated sympathetic neurons. I. Establishment of long-term growth in culture and studies of differentiated properties. J Cell Biol 59:329-345.

Mascorro JA, Yates RD (1980) Paraneurons and paraganglia: histological and ultrastructural comparisons between intraganglionic paraneurons and extra-adrenal paraganglion cells. In: Histochemistry and cell biology of autonomic neurons, SIF cells, and paraneurons (Eränkö O, Soinila S, Päivärinta H, eds), pp 201-213. New York: Raven.

Matthew WD, Patterson PH (1983) The production of a monoclonal antibody that blocks the action of a neurite outgrowth-promoting factor. Cold Spring Harbor Symp Quant Biol 48:625-631.

Matthew WD, Sandrock AW (1987) Cyclophosphamide treatment used to manipulate the immune response for the production of monoclonal antibodies. J Immunol Methods 100:73-82.

Nawa H, Sah DW (1990) Different biological activities in conditioned media control the expression of a variety of neuropeptides in cultured sympathetic neurons. Neuron 4:279-287.

Norton FL, Benjamini E (1987) Studies on the suppression of the immune response to a defined protein epitope by anti-idiotypic antibodies. Cell Immunol 109:419-428.

Ou S, McDonald C, Patterson PH (1991) Comparison of two techniques for targeting the production of monoclonal antibodies against particular antigens. J Immunol Meth, in press.

Päivärinta H, Eränkö O (1982) Number of neurons and dexamethasone-induced SIF cells in developing sympathetic ganglia and in intraocular ganglion transplants. J Auton Nerv Syst 5:219-230.

Päivärinta H, Soinila S, Eränkö O (1984) Effect of pre- and/or postganglionic nerve division on hydrocortisone-induced small intensely fluorescent cells in the rat superior cervical ganglion. Neuroscience 12:67-75.

Pearse AGE, Polak JM, Rost FWD, Fontaine J, Le Lievre C, Le Douarin N (1973) Demonstration of the neural crest origin of type I (APUD) cells in the avian carotid body, using a cytochemical marker system. Histochemie 34:191-203.

Rohrer H, Thoenen H (1987) Relationship between differentiation and terminal mitosis: chick sensory and ciliary neurons differentiate after terminal mitosis of precursor cells, whereas sympathetic neurons continue to divide after differentiation. J Neurosci 7:3739-3748.

Rothman TP, Gershon MD, Holtzer H (1978) The relationship of cell division to the acquisition of adrenergic characteristics by developing sympathetic ganglion cell precursors. Dev Biol 65:322-341.

Seidl K, Unsicker K (1989) Survival and neuritic growth of sympathoadrenal (chromaffin) precursor cells in vitro. Int $\mathbf{J}$ Dev Neurosci $7: 465-473$.

Soinila S (1984) Pre- and postnatal development of the small intensely fluorescent cells in the rat superior cervical ganglion. Int J Dev Neurosci 2:65-76.

Soinila S, Eränkö O (1984) Intensely fluorescent cells in embryonic and postnatal superior cervical ganglia of the rat cultured with and without hydrocortisone. J Auton Nerv Syst 11:43-57.

Stemple DL, Mahanthappa NK, Anderson DJ (1988) Basic FGF induces neuronal differentiation, cell division, and NGF dependence in chromaftin cells: a sequence of events in sympathetic development. Neuron 1:517-525.

Suzue T, Kaprielian Z, Patterson PH (1990) A monoclonal antibody that defines rostrocaudal gradients in the mammalian nervous system. Neuron 5:421-431.

Taggart RT, Samloff M (1983) Stable antibody-producing murine hybridomas. Science 219:1228-1230.

Taxi J (1979) The chromaffin and chromaffin-like cells in the autonomic nervous system. Int Rev Cytol 57:283-343.

Taxi J, Derer M, Domich A (1983) Morphology and histophysiology of SIF cells. In: Autonomic ganglia (Elfvin L-G, ed), pp 67-95. New York: Wiley.

Teitelman GH, Gershon MD, Rothman TP, Joh TH, Reis DJ (1981) Proliferation and distribution of cells that transiently express a catecholaminergic phenotype during development in mice and rats. Dev Biol 86:348-355.

Uemura Y, Sugimoto T, Nomura S, Nagatsu I, Mizuno N (1987) Tyrosine hydroxylase-like immunoreactivity and catecholamine fluorescence in ciliary ganglion neurons. Brain Res 416:200-203.

Unsicker K, Lietzke R (1987) Chromaffin cells: modified neurons that are both targets and storage sites of neuronotrophic and neurite promoting factors. NATO ASI Series, Series H 00:367-384.

Unsicker K, Krisch B, Otten U, Thocnen H (1978) Nerve growth factor-induced fiber outgrowth from isolated rat adrenal chromaffin cells: impairment by glucocorticoids. Proc Natl Acad Sci USA 75: 3498-3502.

Unsicker K, Skaper SD, Varon S (1985) Neuronotrophic and neuritepromoting factors: effects on early postnatal chromaffin cells from adrenal medulla. Dev Brain Res 17:117-129.

Unsicker K, Seidl K, Hofmann HD (1989) The neuro-endocrine ambiguity of sympathoadrenal cells. Int J Dev Neurosci 7:413-417.

Verhofstad AAJ, Coupland RE, Parker TR, Goldstein M (1985) Immunohistochemical and biochemical study on the development of the noradrenaline- and adrenaline-storing cells of the adrenal medulla of the rat. Cell Tissue Res 242:233-243.

Winkler H, Apps DK, Fischer-Colbrie R (1986) The molecular function of adrenal chromaffin granules: established facts and unresolved topics. Neuroscience 18:261-290. 